Morgan, J., Gulick, S., Mellett, C.L., Green, S.L., and the Expedition 364 Scientists

Proceedings of the International Ocean Discovery Program Volume 364

publications.iodp.org

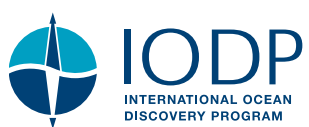

https://doi.org/10.14379/iodp.proc.364.101.2017

\section{Expedition 364 summary ${ }^{1}$}

Check for updates

S. Gulick, J. Morgan, C.L. Mellett, S.L. Green, T. Bralower, E. Chenot,

G. Christeson, P. Claeys, C. Cockell, M. Coolen, L. Ferrière, C. Gebhardt, K. Goto, H. Jones, D. Kring, J. Lofi, C. Lowery, R. Ocampo-Torres, L. Perez-Cruz, A.E. Pickersgill, M. Poelchau, A. Rae, C. Rasmussen, M. Rebolledo-Vieyra, U. Riller, H. Sato, J. Smit, S. Tikoo, N. Tomioka, J. Urrutia-Fucugauchi, M. Whalen, A. Wittmann, K. Yamaguchi, L. Xiao, and W. Zylberman ${ }^{2}$

Keywords: International Ocean Discovery Program, IODP, International Continental Scientific Drilling Program, ICDP, L/B Myrtle, Mission Specific Platform, Expedition 364, Site M0077, Hole M0077A, Gulf of México, Yucatán shelf, Chicxulub, impact crater, crater modification, multi-ring basin, peak ring, uplifted continental crust, impact melt rock, planar deformation features, Cretaceous/Paleogene boundary, PETM, K-Pg boundary, Cretaceous-Paleogene mass extinction, shock metamorphism, carbon isotope excursions, hydrothermal, geomagnetic reversal, shatter cone, ejecta, suevite, granitoid, pelagic limestone, tsunamite
Contents

$\begin{aligned} 1 & \text { Abstract } \\ \mathbf{2} & \text { Introduction } \\ \mathbf{2} & \text { Background } \\ \mathbf{7} & \text { Scientific objectives } \\ 11 & \text { Operational strategy } \\ 12 & \text { Principal results } \\ \mathbf{2 0} & \text { Preliminary scientific assessment } \\ \mathbf{2 0} & \text { References }\end{aligned}$

1 Abstract

7 Scientific objectives

11 Operational strategy

20 Preliminary scientific assessment

20 References

\section{Abstract}

The Chicxulub impact crater, on the Yucatán Peninsula of México, is unique. It is the only known terrestrial impact structure that has been directly linked to a mass extinction event and the only terrestrial impact with a global ejecta layer. Of the three largest impact structures on Earth, Chicxulub is the best preserved. Chicxulub is also the only known terrestrial impact structure with an intact, unequivocal topographic peak ring. Chicxulub's role in the Cretaceous/Paleogene (K-Pg) mass extinction and its exceptional state of preservation make it an important natural laboratory for the study of both large impact crater formation on Earth and other planets and the effects of large impacts on the Earth's environment and ecology. Our understanding of the impact process is far from complete, and despite more than 30 years of intense debate, we are still striving to answer the question as to why this impact was so catastrophic.

During International Ocean Discovery Program (IODP) and International Continental Scientific Drilling Program (ICDP) Expedition 364, Paleogene sedimentary rocks and lithologies that make up the Chicxulub peak ring were cored to investigate (1) the nature and formational mechanism of peak rings, (2) how rocks are weakened during large impacts, (3) the nature and extent of post-impact hydrothermal circulation, (4) the deep biosphere and habitability of the peak ring, and (5) the recovery of life in a sterile zone. Other key targets included sampling the transition through a rare midlatitude Paleogene sedimentary succession that might include Eocene and Paleocene hyperthermals and/or the Paleocene/Eocene Thermal
Maximum (PETM); the composition and character of suevite, impact melt rock, and basement rocks in the peak ring; the sedimentology and stratigraphy of the Paleocene-Eocene Chicxulub impact basin infill; the geo- and thermochronology of the rocks forming the peak ring; and any observations from the core that may help constrain the volume of dust and climatically active gases released into the stratosphere by this impact. Petrophysical properties measurements on the core and wireline logs acquired during Expedition 364 will be used to calibrate geophysical models, including seismic reflection and potential field data, and the integration of all the data will calibrate models for impact crater formation and environmental effects. The drilling directly contributes to IODP Science Plan goals:

Climate and Ocean Change: How does Earth's climate system respond to elevated levels of atmospheric $\mathrm{CO}_{2}$ ? How resilient is the ocean to chemical perturbations? The Chicxulub impact represents an external forcing event that caused a $75 \%$ species level mass extinction. The impact basin may also record key hyperthermals within the Paleogene.

Biosphere Frontiers: What are the origin, composition, and global significance of subseafloor communities? What are the limits of life in the subseafloor? How sensitive are ecosystems and biodiversity to environmental change? Impact craters can create habitats for subsurface life, and Chicxulub may provide information on potential habitats for life, including extremophiles, on the early Earth and other planetary bodies. Paleontological and geochemical studies at ground zero will document how large impacts affect ecosystems and biodiversity.

\footnotetext{
${ }^{1}$ Gulick, S., Morgan, J., Mellett, C.L., Green, S.L., Bralower, T., Chenot, E., Christeson, G., Claeys, P., Cockell, C., Coolen, M.J.L., Ferrière, L., Gebhardt, C., Goto, K., Jones, H., Kring, D., Lofi, J., Lowery, C., Ocampo-Torres, R., Perez-Cruz, L., Pickersgill, A.E., Poelchau, M., Rae, A., Rasmussen, C., Rebolledo-Vieyra, M., Riller, U., Sato, H., Smit, J., Tikoo, S., Tomioka, N., UrrutiaFucugauchi, J., Whalen, M., Wittmann, A., Yamaguchi, K., Xiao, L., and Zylberman, W., 2017. Expedition 364 summary. In Morgan, J., Gulick, S., Mellett, C.L., Green, S.L., and the Expedition 364 Scientists, Chicxulub: Drilling the K-Pg Impact Crater. Proceedings of the International Ocean Discovery Program, 364: College Station, TX (International Ocean Discovery Program). https://doi.org/10.14379/iodp.proc.364.101.2017

2 Expedition 364 Scientists' addresses.

MS 364-101: Published 30 December 2017

This work is distributed under the Creative Commons Attribution 4.0 International (CC BY 4.0) license. (cc))B
} 
Earth Connections/Earth in Motion: What mechanisms control the occurrence of destructive earthquakes, landslides, and tsunami? Drilling into the uplifted rocks that form the peak ring will be used to groundtruth numerical simulations and model impact-generated tsunami, and deposits on top of the peak ring and around the Gulf of México will inform us about earthquakes, landslides, and tsunami generated by Chicxulub. These data will collectively help us understand how impact processes are recorded in the geologic record and their potential hazards.

IODP Expedition 364 was a Mission Specific Platform expedition designed to obtain subseabed samples and downhole logging measurements from the post-impact sedimentary succession and the peak ring of the Chicxulub impact crater. A single borehole (Hole M0077A) was drilled into the Chicxulub impact crater on the Yucatán continental shelf, recovering core from 505.70 to 1334.69 meters below seafloor (mbsf) with $\sim 99 \%$ core recovery. Downhole logs were acquired for the entire depth of the borehole.

\section{Introduction}

Peak rings are rings of hills that are emergent above crater floors within large impact basins on terrestrial planets (Figure F1), and

Figure F1. Peak rings are roughly circular rings of rugged hills and massifs that stand above the otherwise flat crater floor. In peak-ring basins, the crater rim is the outer edge of a terrace zone. In multi-ring basins, two or more rings (inward-facing asymmetric scarps) lie outboard of the central basin. Photo credit: NASA.

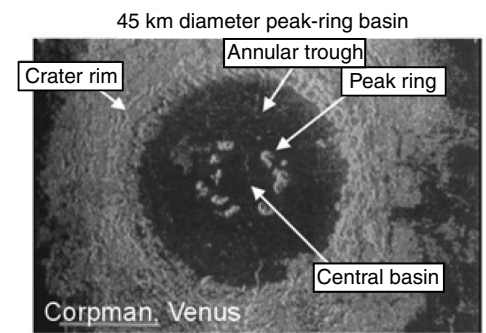

$145 \mathrm{~km}$ diameter multi-ring basin
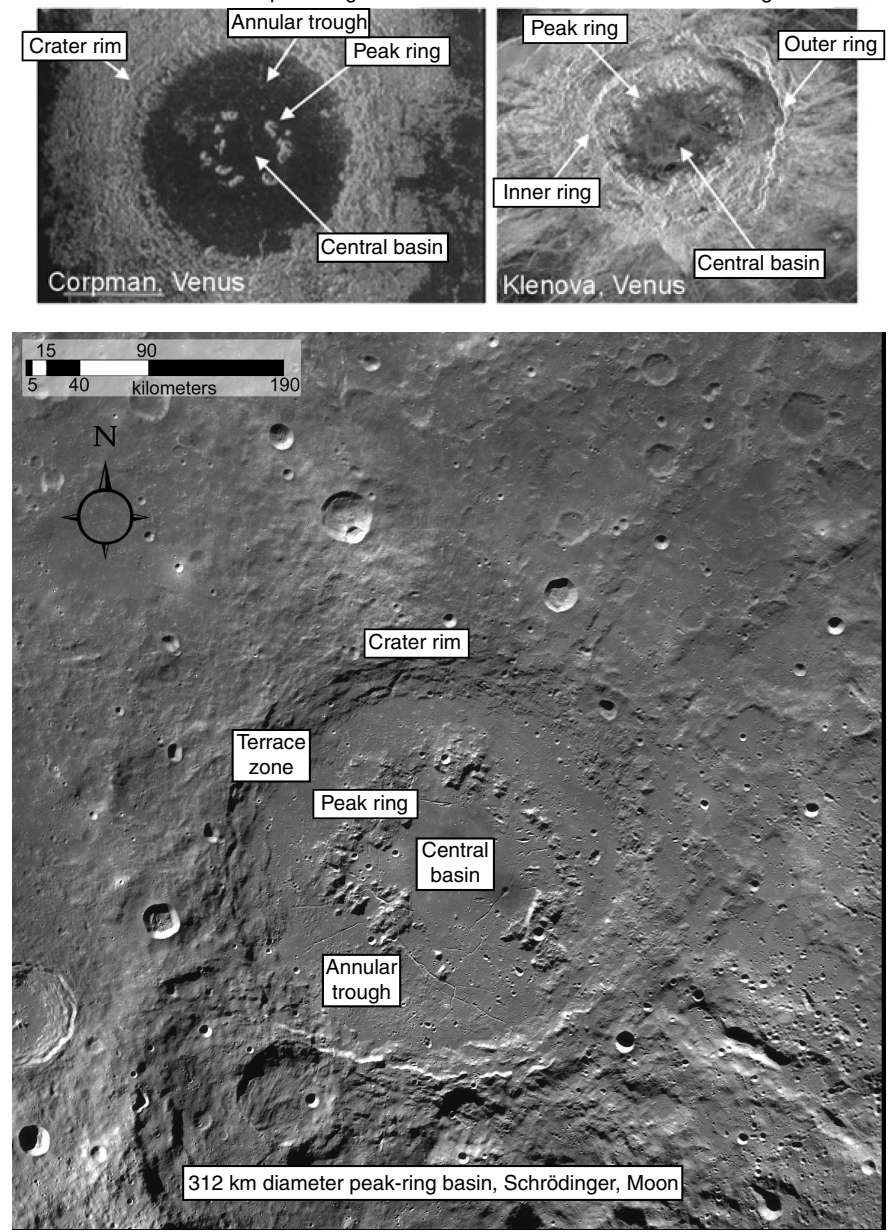

there is no consensual agreement on either their formational mechanism or the nature of the rocks that comprise them (Grieve et al., 2008; Baker et al., 2016). Geophysical data indicate that the peak ring at Chicxulub is formed from rocks that have low velocity and density, and one explanation for this is that they are highly fractured and porous (Morgan et al., 2000, 2011; Gulick et al., 2013). Immediately after impact, the peak ring was submerged under water and located adjacent to a thick pool of hot impact melt. Hence, we would expect intense hydrothermal activity within the peak ring (Ames et al., 2004; Zürcher and Kring, 2004). This activity may have provided a niche for exotic life forms possibly similar to that of hydrothermal vent systems in the oceans. Drilling the peak ring will allow us to determine the origin, lithology, and physical state of the rocks that form it; distinguish between competing models of peakring formation; and document hydrothermal systems, microbiology, and post-impact processes and recovery.

\section{Background}

\section{The peak ring}

The term "peak ring" was first used to describe the often discontinuous, mountainous ring that rises above the floor of large craters on the moon. Peak rings are internal to the main topographic crater rim (Figure F1). Since they were first identified on the Moon, peak rings have been observed in large terrestrial craters on all large silicate planetary bodies. Notably, peak rings do not appear to occur on the icy satellites of Jupiter and Saturn, which indicates that crustal rheology plays a role in their formation. The peak ring is a topographic feature; it protrudes through the impact melt rock and breccia that lines the floor of the crater and stands above the surrounding terrain. As a result, the unequivocal identification of a peak ring in Earth's largest craters is compromised by inevitable erosion and/or tectonism.

Two seismic experiments were conducted in 1996 and 2005 (Figure F2) across the Chicxulub impact structure (Morgan et al.,

Figure F2. Location of site survey data overlain on the gravity field. Coastline is in white. Small black dots are cenotés. Marine seismic profiles acquired in 1996 and 2005 are shown in black dashed and solid lines, respectively. Offshore and onshore seismometer locations in the 1996 and 2005 surveys are shown with large black and white circles, respectively. Existing well locations are shown with yellow squares. Hole M0077A is shown with a yellow triangle. Modified from Gulick et al. (2013); from Reviews of Geophysics.

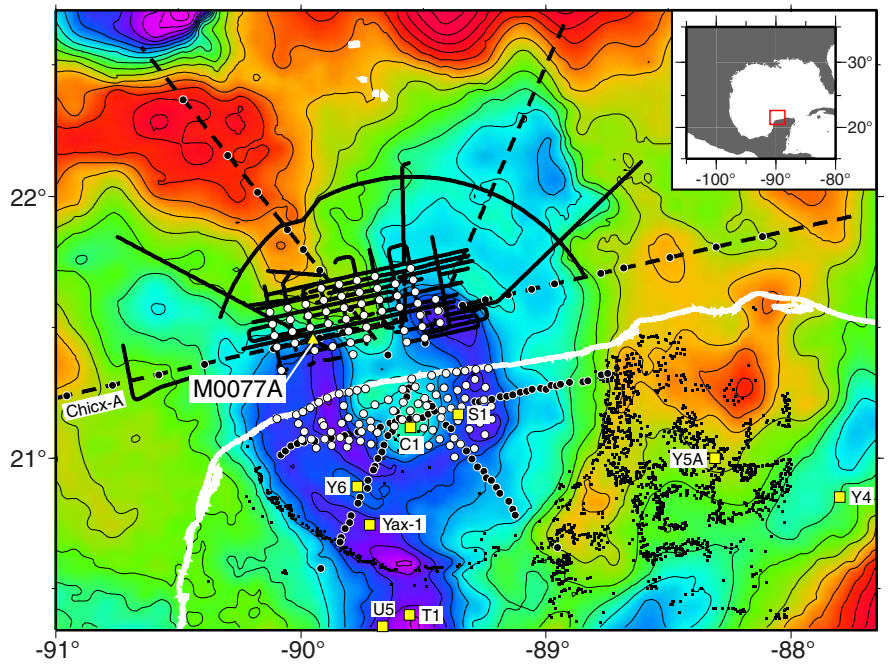


1997; Gulick et al., 2008). Reflection and refraction seismic data image lithologies and structures to the base of the crust at about $35 \mathrm{~km}$ depth (Christeson et al., 2009; Gulick et al., 2013). The impact basin is buried beneath a few hundred meters of Cenozoic sedimentary rock, and the present-day Cretaceous-Paleogene (K-Pg) surface deepens to $\sim 1 \mathrm{~s}$ two-way traveltime $(\sim 1 \mathrm{~km})$, revealing a $\sim 145 \mathrm{~km}$ diameter post-impact basin (Morgan and Warner, 1999) with ringshaped faults reaching diameters $>200 \mathrm{~km}$ (Gulick et al., 2008). Within this post-impact basin, there is an $\sim 80 \mathrm{~km}$ diameter topographic ring that appears analogous to peak rings observed on other planetary bodies (compare Figures F1, F3, F4). Reflective pre-impact stratigraphy (the Mesozoic sediments) can be tracked around the crater (Whalen et al., 2013), and large offsets in the stratigraphy define a 20-35 km wide terrace (or megablock) zone (Figure F3) (Gulick et al., 2008, 2013). Morgan and Warner (1999) argue that the head scarp of this terrace zone is analogous to the crater rim in peak-ring craters (Figure F1), and rings outside the head scarp (Fig- ure F3) suggest that Chicxulub is a multi-ring basin (Morgan et al., 1997; Gulick et al., 2008). The acquired seismic data show that the water was deeper and the Mesozoic sediments thicker in the northeast quadrant of the crater than in the other quadrants (Bell et al., 2004; Gulick et al., 2008) and that lateral variation in the target at the impact site might explain the current crater asymmetry (Collins et al., 2008). Velocities and densities of the rocks that form the peak ring are low (Morgan et al., 2000; Vermeesch and Morgan, 2008; Barton et al., 2010), and a high-resolution velocity model obtained using full-waveform inversion (Figure F4) shows that the uppermost peak ring is formed from about $100-150 \mathrm{~m}$ of rocks with low $P$-wave velocity (3000-3200 m/s) (Morgan et al., 2011).

Given the lack of intact peak rings exposed at the Earth's surface, there is no consensus as to either their geologic nature (of what material are they composed and from what stratigraphic location this material originates) or the mode of formation of a peak ring. $\mathrm{Nu}$ merical simulations of large-crater formation suggest that they are

Figure F3. Seismic reflection data along Chicx-A (see Figure F2 for location). At about 20-30 km outboard of the crater rim at Chicxulub, the relatively undisturbed, flat-lying, pre-impact stratigraphy is abruptly offset vertically by $400-500 \mathrm{~m}$ (outer ring). The outer ring faults are observed out to radial distances of 90-120 km, giving a crater diameter of 195-210 km (Morgan et al., 1997; Gulick et al., 2008). Projected location of Site M0077 shown. Modified from Gulick et al. (2008); from Nature Geoscience.

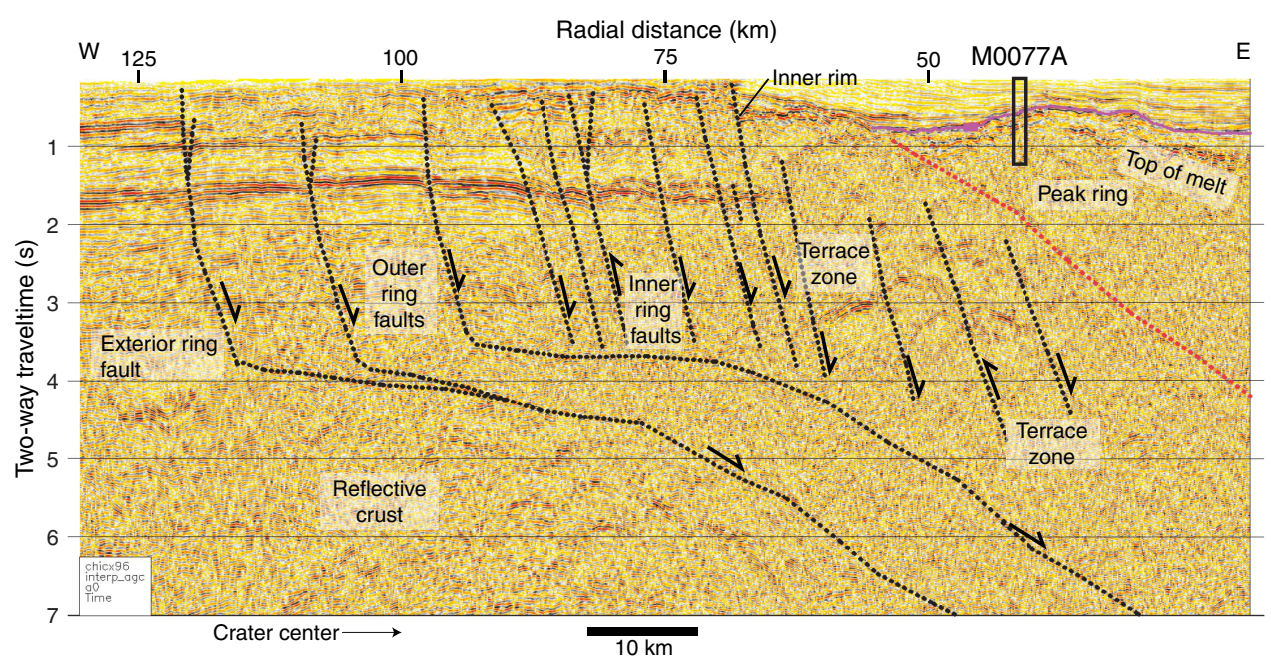

Figure F4. Hole M0077A projected onto a seismic reflection profile and velocity model obtained from full-waveform inversion. Core was recovered between 505.7 and $1334.69 \mathrm{mbsf}$. The principal targets were the PETM at $\sim 600 \mathrm{mbsf}$, followed by the K-Pg boundary at $\sim 650 \mathrm{mbsf}$ and the rocks that form the peak ring. The uppermost peak-ring rocks are formed from 100-150 m of low-velocity material, below which there is a low-frequency reflector coincident with an increase in velocity. Modified from Morgan et al. (2011); from Journal of Geophysical Research: Solid Earth.

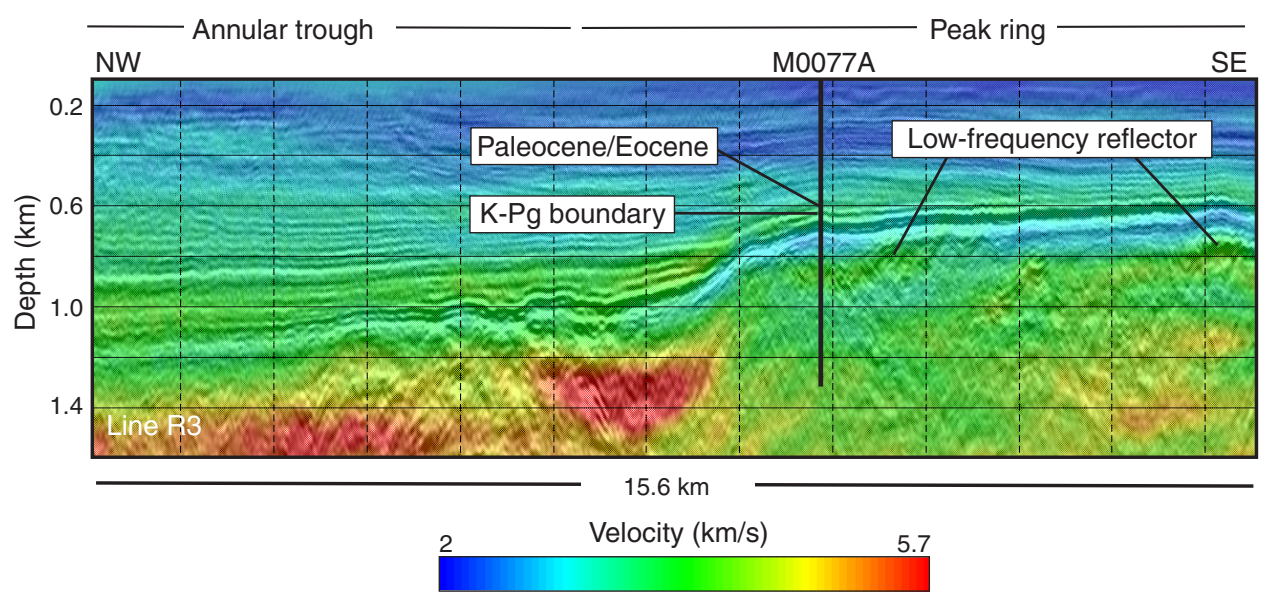


Figure F5. Hydrocode simulation of the formation of the Chicxulub crater (Collins et al., 2002; Morgan et al., 2011). Layering shows stratigraphy; impact point and center of crater are at a horizontal distance of $0 \mathrm{~km}$. (A) Sedimentary rock that forms the transient cavity rim collapsed inward and downward, whereas (B) material in the central crater collapsed upward. C. In this model, the stratigraphically uplifted material (central uplift) collapses outward across the downthrown rim material to form a peak ring. D. Cross section through the final crater. Color shows maximum shock pressures to which rocks have been subjected during crater formation. Dashed line = location of sediments that originally formed the transient cavity rim (see A). Modified from Morgan et al. (2011); from Journal of Geophysical Research: Solid Earth.

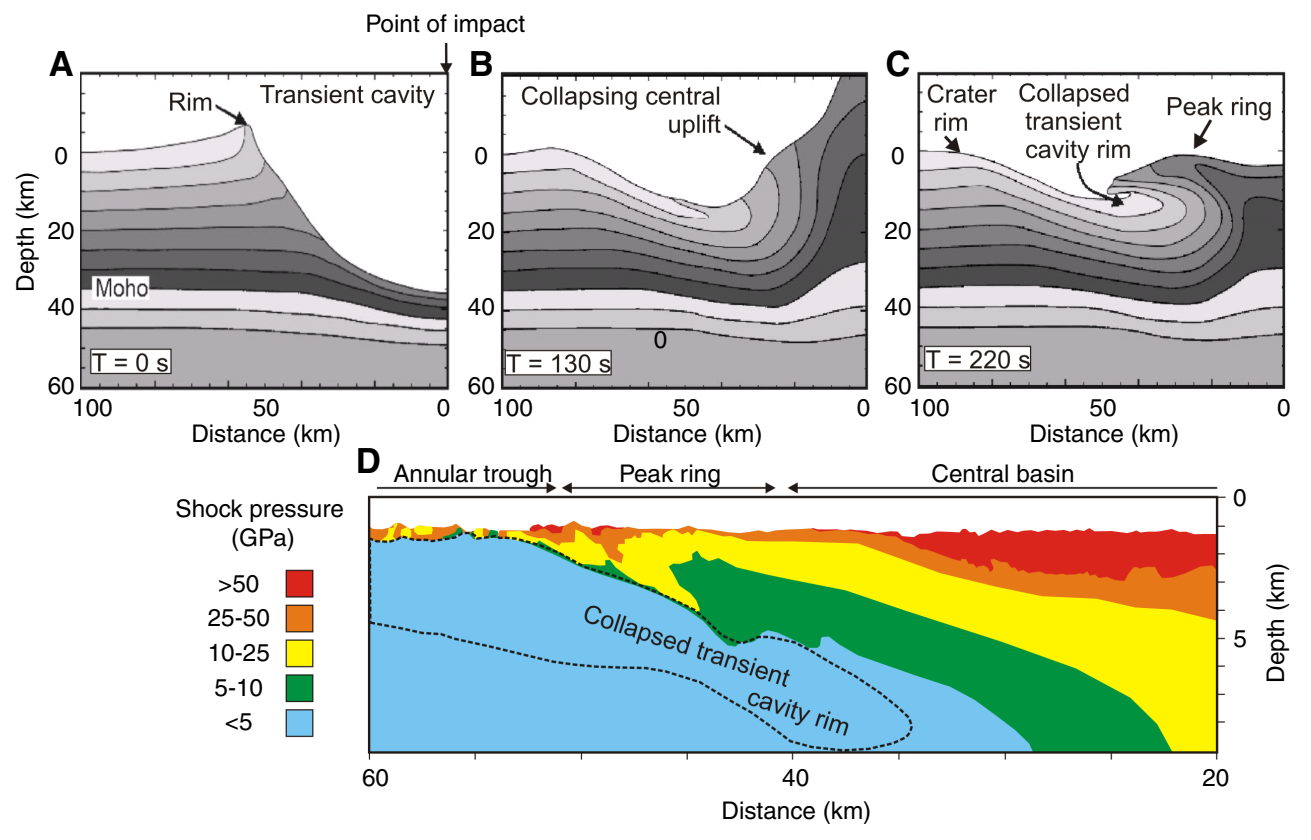

formed during the collapse of a deep bowl-shaped "transient cavity" formed during the initial stages of cratering (Figure F5) (Morgan et al., 2000; Collins et al., 2002; Ivanov, 2005; Senft and Stewart, 2009). During this collapse, structural uplift of the crater floor produces a central uplift, which is overheightened and unstable under gravity. The subsequent outward collapse of the central uplift leads to the formation of a ring of peaks between the crater center and the crater rim (Morgan et al., 2000, 2011). This model for peak-ring formation is consistent with seismic data that show inward-collapsed Mesozoic rocks lie directly beneath the peak ring at Chicxulub at all azimuths (Morgan et al., 2000; Gulick et al., 2013). However, the precise kinematics and details of the mechanics of cavity modification remain unclear. Moreover, that such an emphatic collapse of the transient crater occurs at all requires substantial weakening of target rocks relative to their static laboratory-measured strength (Melosh, 1979; O'Keefe and Ahrens, 1993). In numerical models, the precise kinematics of crater collapse and peak-ring formation is dependent on near-surface rheology, as well as the spatial extent, nature, and timing of the weakening of the target rocks (e.g., Wünnemann et al., 2005).

\section{Previous drilling}

Petróleos Méxicanos (PEMEX) drilled several deep ( 1.6km) holes into or close to the Chicxulub crater (Figure F2), completing their drilling in the mid-1970s (Figure F6). Unfortunately, the amount of coring was limited, and their interest in the area waned after they intercepted Paleozoic basement and impactites without any sign of hydrocarbons. Very few samples of the impact lithologies found in these wells are now available for examination. The Universidad Nacional Autónoma de México (UNAM) conducted a shallow drilling program in the 1990s, during which impact litho- logies were penetrated at three sites on the exterior of the crater rim: U5, U6, and U7 (Urrutia-Fucugauchi et al., 1996). International Continental Scientific Drilling Project (ICDP) Borehole Yaxcopoil-1 (Yax-1) was drilled $\sim 60 \mathrm{~km}$ south-southwest of the crater center (Stöffler et al., 2004; Urrutia-Fucugauchi et al., 2004b) within the impact basin and inside a ring of cenotes (Figure F2). The general stratigraphy of the Chicxulub crater was constructed using the available core from these programs and the original PEMEX logs (Figure F6) (Ward et al., 1995; Rebolledo-Vieyra and UrrutiaFucugauchi, 2004).

The onshore wells indicate that post-impact sedimentary rock deepens from $\sim 1100 \mathrm{~m}$ within the center of the post-impact basin to $\sim 1.1 \mathrm{~km}$ within the center of the post-impact basin; this thickening of the Cenozoic sequence is in agreement with the offshore seismic data. Within the impact basin, Wells $\mathrm{C} 1, \mathrm{~S} 1$, and Y6 penetrated a few hundred meters of suevite and 100-250 m of impact melt rock, whereas outside the basin, Wells T1, Y2, Y5A, Y1, and Y4 penetrated a few hundred meters of polymictic breccia, which may or may not contain suevite (Hildebrand et al., 1991; Sharpton et al., 1996; Urrutia-Fucugauchi et al., 2011). Several of the wells penetrated thick sequences of Cretaceous rocks. Close to the structure, these Cretaceous sequences are $\sim 2 \mathrm{~km}$ thick and comprise dolomites and carbonates, with some thick beds of Lower Cretaceous anhydrite. Wells Y1 and Y2 penetrated Paleozoic basement at 3.3 $\mathrm{km}$ depth. UNAM Well U5 shows Cenozoic rocks above suevite, and in Well U7, suevite overlies polymictic breccia composed mainly of sedimentary clasts rich in evaporitic material (UrrutiaFucugauchi et al., 2008). The suevites have high magnetic susceptibilities and the lower breccia has low magnetic susceptibilities (Urrutia-Fucugauchi et al., 1996; Rebolledo-Vieyra and UrrutiaFucugauchi, 2006). In Well U6, Cenozoic rocks directly overlie this 
Figure F6. A. Location map of the State of Yucatán showing onshore drill holes from the UNAM scientific drilling program (Holes U1-U8), the ICDP borehole (Yax-1), and PEMEX drilling. All parts modified from Rebolledo-Vieyra and Urrutia-Fucugauchi (2004); from Meteorics \& Planetary Science. (Continued.)

A

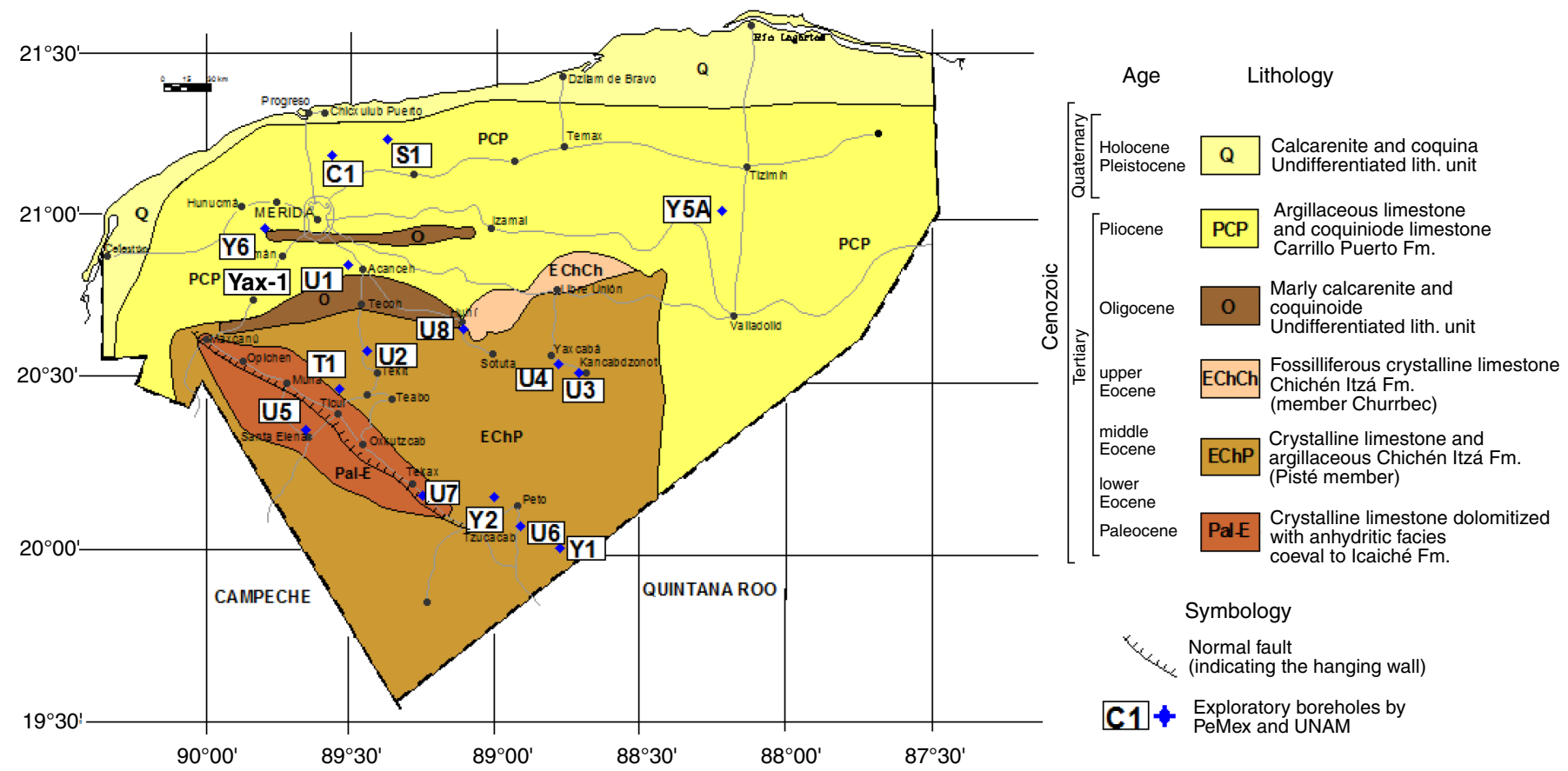

polymictic breccia, with an erosional contact between them. The polymictic breccia in the two UNAM wells could be equivalent to the breccia observed in Wells Y4, Y1, Y5A, Y2, and T1. No onshore wells have penetrated the peak ring, and no previous offshore wells were drilled into the Chicxulub impact structure.

ICDP Borehole Yax-1 is located $\sim 60 \mathrm{~km}$ radial distance from the crater center and is positioned interior of the crater rim. Drilling recovered core from the $\sim 800 \mathrm{~m}$ thick Cenozoic sequence, suevite, and underlying parautochthonous Cretaceous rocks to $1511 \mathrm{~m}$ below the surface (Urrutia-Fucugauchi et al., 2004b). The earliest Cenozoic sediments indicate gravity flows and resurge deposits formed part of the initial crater fill (Goto et al., 2004; Whalen et al., 2008,2013 ) and contain geochemical evidence for long-lasting hydrothermal venting into the ocean (Rowe et al., 2004; Zürcher and Kring, 2004). Unfortunately, its location on a steep slope meant studies of the post-impact section were plagued by coarse-grained redeposited carbonates and lithification, and the very basal Paleocene appears to be missing (Arz et al., 2004; Smit et al., 2004; Rebolledo-Vieyra and Urrutia-Fucugauchi, 2004; Whalen et al., 2013). The $100 \mathrm{~m}$ thick melt-rich impactite sequence is complex and composed of six distinct units (Claeys et al., 2003; Kring et al., 2004; Stöffler et al., 2004; Wittmann et al., 2007), which were modified by post-impact hydrothermal circulation (Hecht et al., 2004). The Cretaceous rocks appear to be formed from a number of megablocks composed of dolomite, limestone, and about $27 \%$ anhydrite that have rotated relative to each other, probably during the crater modification stage (Kenkmann et al., 2004). The megablock lithologies are intruded by suevitic dikes, impact melt rock dikes, and clastic, polymict dikes (Wittmann et al., 2004). 
Figure F6 (continued). B. Lithologic columns and stratigraphy from PEMEX and Yax-1 boreholes. Site M0077 is $\sim 45 \mathrm{~km}$ from the crater center. (Continued.)

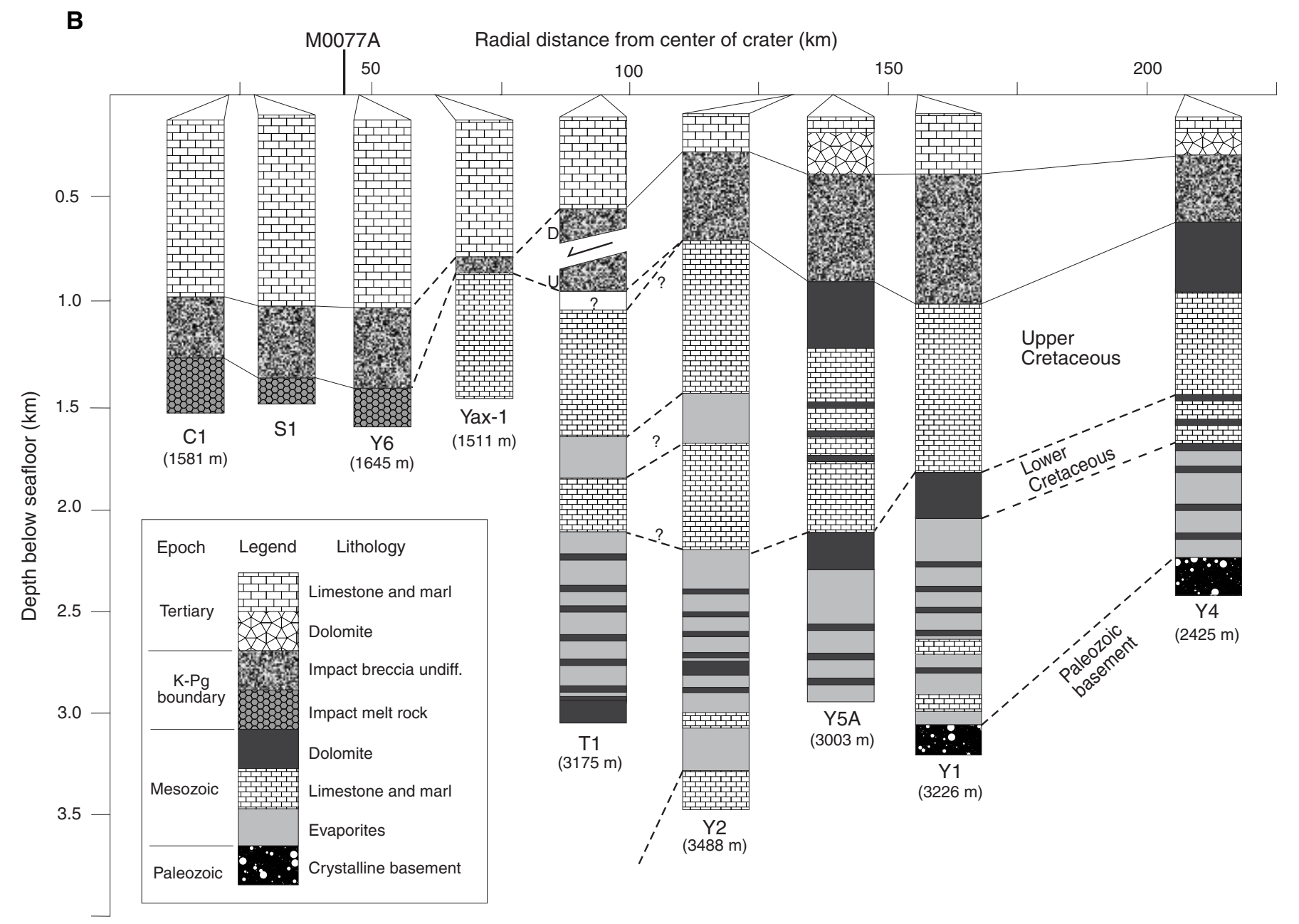


Figure F6 (continued). C. Lithologic columns and stratigraphy from UNAM and Yax-1 boreholes.

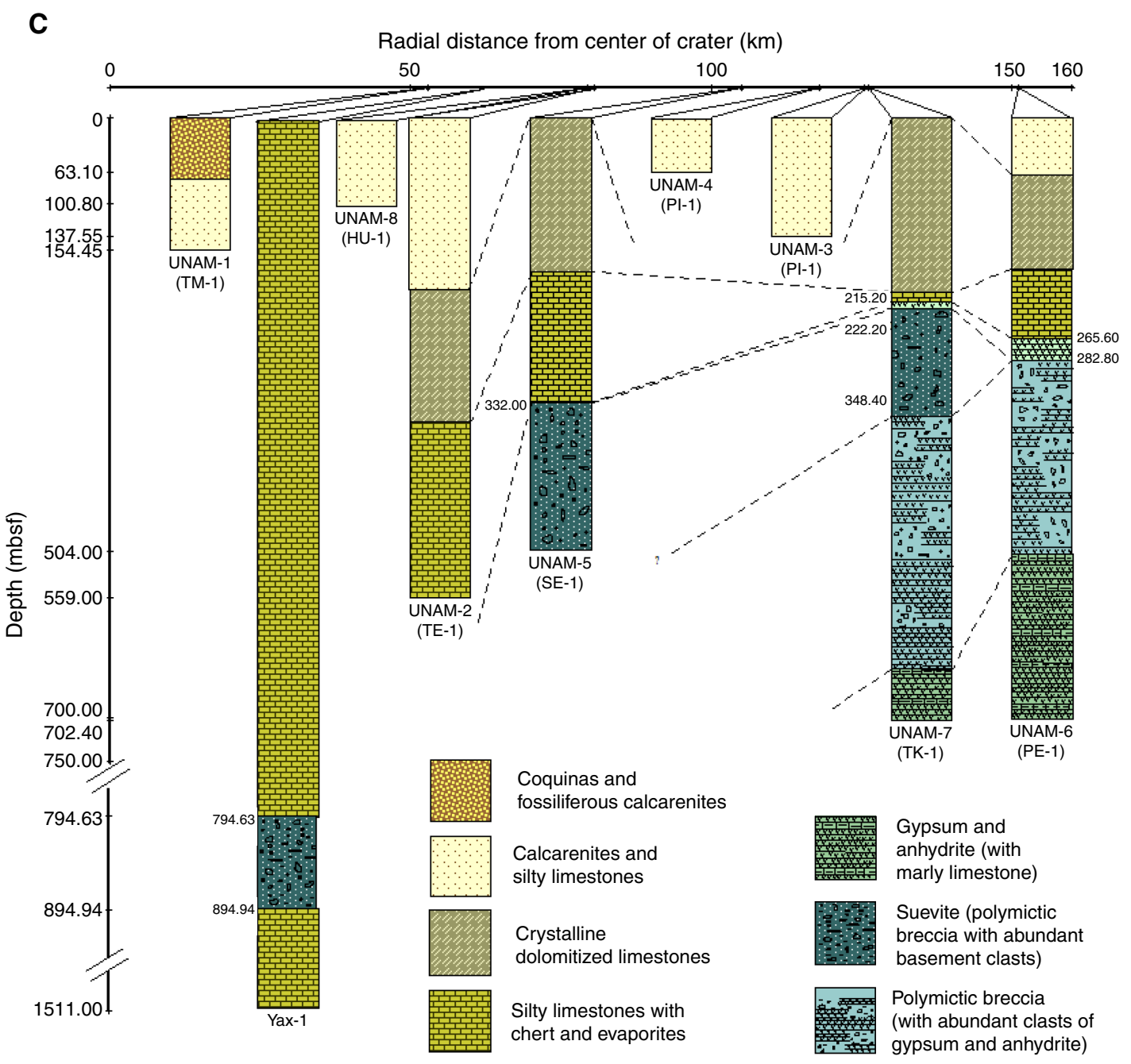

\section{Scientific objectives}

Expedition 364 was designed to address the following objectives through drilling at Site M0077:

- The nature and formation of a topographic peak ring;

- How rocks are weakened during large impacts to allow them to collapse and form relatively wide, flat craters;

- The nature and extent of post-impact hydrothermal circulation;

- The habitability of the peak ring and effect of this impact on the modern and ancient deep biosphere;

- The recovery of life in a sterile zone;

- The nature of the Eocene and Paleocene hyperthermals and the PETM transition;

- The nature and composition of the suevite, impact melt rock, and basement rocks of the peak ring;

- The volume of dust and climatically active gases released into the stratosphere by this impact;

- The climatic effects of this impact;

- The sedimentology and stratigraphy of the Paleocene-Eocene Chicxulub impact basin infill;

- The geo- and thermochronology of the rocks forming the peak ring;
- Petrophysical properties measured on cores and downhole to calibrate geophysical models and integrate with seismic velocity data; and

- Integration of all data to calibrate impact crater models for crater formation and environmental effects.

\section{The nature and formation of peak rings}

Hole M0077A sampled material that forms a peak ring (Figure F4) and reveals the lithologic and physical state of these rocks, including porosity, fracturing, and extent of shock effects. The recovered core will be used to test the working hypotheses that peak rings are formed from (1) overturned and uplifted basement rocks, (2) megabreccias, or (3) some other material. If the peak ring is formed from uplifted rocks, as predicted by several independent numerical simulations of crater formation (Figure F5) (Collins et al., 2002; Ivanov, 2005; Senft and Stewart, 2009), then we can estimate their depth of origin (upper crust or deeper) using metamorphic grade, thermochronology, and possibly remanent magnetism. The orientation of impact-induced discontinuities, which may include breccia zones, brittle shear faults, and melt-filled fractures, will be used to infer the strain geometry (i.e., the orientation) and potentially also the magnitude of the three principal strain axes during peak-ring formation and thus constrain the kinematics of peak-ring 
formation. Collectively, these data will be used to discriminate between models of peak-ring formation and to groundtruth dynamic models of crater formation (Figure F5), which now include dilatancy-in other words, a mechanism for the increase in porosity during cratering and the cause of the gravity low across impact craters (Collins, 2014). For example, in the numerical simulations shown in Figure F5, shock pressures experienced by peak-ring rocks are predicted to be between 10 and $50 \mathrm{GPa}$, whereas they are expected to be relatively lower on average in the peak-ring formation model by Baker et al. (2016), which is based on analyses of peak-ring craters on the moon and Mercury.

\section{The weakening mechanism}

Numerical modeling of large impacts indicates that rocks must behave in a fluid-like manner for a short period of time after impact to allow the dramatic collapse of a large bowl-shaped transient cavity to form a broad, flat final crater (Melosh and Ivanov, 1999). In these models, the material that forms the peak ring has traveled the greatest distance during crater formation (e.g., Figure F5) and thus should have undergone the most mechanical weakening. Providing a physical explanation for the apparent transitory low strength of the target is an enduring and challenging problem in impact cratering mechanics. Proposed weakening mechanisms include acoustic fluidization (Melosh, 1979; Melosh and Ivanov, 1999), thermal softening (O'Keefe and Ahrens, 1993), and strain-rate weakening (Senft and Stewart, 2009). Geological investigations at complex craters provide clues to the weakening mechanism, such as evidence for cataclastic flow (Kenkmann, 2003) and the identification of individual blocks surrounded by breccias in accordance with the block model of acoustic fluidization (Ivanov, 1994; Kenkmann et al., 2005; Riller and Lieger, 2008). Eroded complex craters often possess large zones of pseudotachylytic breccia, which may act to reduce friction on fault planes (Spray, 1992; Reimold and Gibson, 2005; MohrWestheide et al., 2009; Riller et al., 2010), although this appears to conflict with observational data that suggest melt was emplaced in a tensional stress regime (Lieger et al., 2009).

Quasistatic mechanical loading tests of intact and brecciated target material will be used to measure the strength difference between friction-controlled deformation of crushed rock and fracture-controlled deformation of intact rock. Such data, along with our analyses of samples of the peak-ring rocks, will be used to investigate what mechanism(s) allow the target rocks to behave temporarily as a fluid in response to hypervelocity impact.

\section{Hydrothermal circulation}

Both the post-impact sediments and peak-ring rocks will be examined for evidence of hydrothermal alteration and post-impact venting into the ocean to answer questions such as how long the circulation lasted and how high the maximum temperature reached. Models of hydrothermal systems in impact craters imply enhanced flow in peak rings (e.g., Figure F7) (Ames et al., 2004; Zürcher and Kring, 2004; Schwenzer and Kring, 2009), and thus Site M0077 is an excellent location to investigate the hydrothermal system at Chicxulub. This line of inquiry will include petrological assessment and thermochronology, as well as X-ray diffraction (XRD), X-ray fluorescence (XRF), fluid inclusion, and stable isotope analyses to examine the alteration assemblage and characterize the composition of the hydrothermal fluids (Ames et al., 2004; Lüders and Rickers, 2004; Zürcher and Kring, 2004; Osinski et al., 2005, 2013). Was hydrothermal circulation focused in specific zones, as it was in Hole Yax-1 (along faults and lithologic contacts), or was it more perva-
Figure F7. Numerical modeling of a hydrothermal system through a peak ring in a large impact structure (redrawn from Abramov and Kring, 2007).

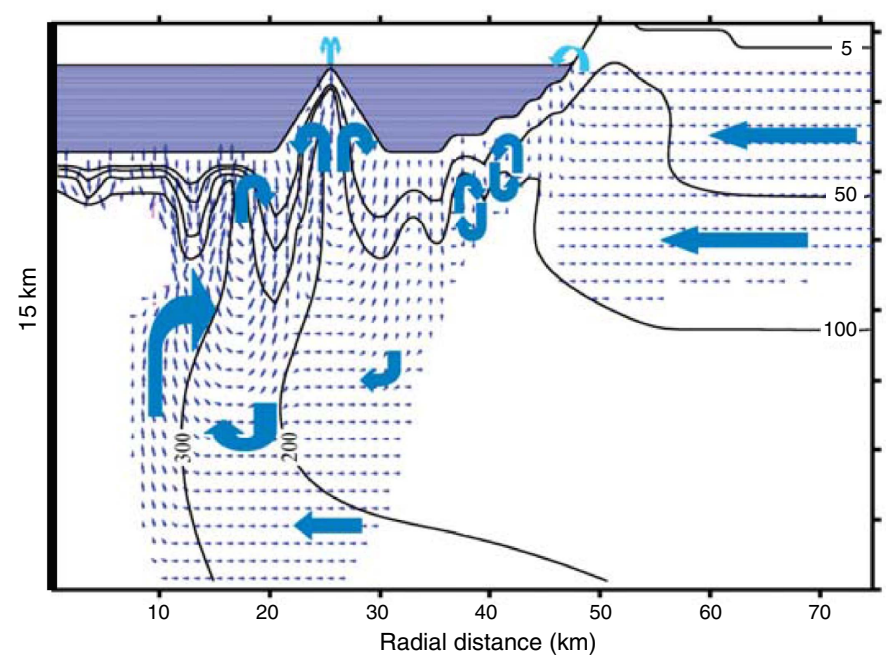

sive? Wireline logs and petrophysical measurements on the core will be used to measure fracture density and porosity, which will help assess ancient permeability-an important parameter in modeling hydrothermal systems (Abramov and Kring, 2007).

\section{Deep biosphere and habitability}

Analyses at different depths of the borehole focusing on samples of melt rock, crystal xenoliths embedded in the melt, and crystals from the peak ring itself will be used to determine the duration of the crater cooling and ultimately provide better quantification of how long a crater stays warm enough to be suitable for life evolution and deep subsurface microbial communities.

Both the post-impact sedimentary rock and peak-ring rocks will be examined for present-day microbiology and biosignatures of past life. Impacts can have an adverse effect on the deep biosphere due to hydrothermal sterilization, but they may also lead to an increase in microbial abundance due to impact-induced fracturing (Cockell et al., 2002, 2005). The diversity of microbial life will be quantified and compared with geological and geochemical data to answer questions such as was the microbiology shaped by the post-impact hydrothermal system, and did organic matter get trapped within hydrothermal minerals? The deep biosphere will be investigated using culturing, molecular biological analyses of DNA, searching for biosignatures such as hopanoids and other lipids/biomolecules, and paired analyses of paleome (the genome of an extinct species) and lipid biomarkers (Cockell et al., 2005; 2009; Coolen and Overmann, 2007; Coolen et al., 2013). Iron isotopes will also be used to detect biosignatures because they are particularly useful for studies of ancient, severely metamorphosed and/or altered rocks (Yamaguchi et al., 2005). The rehabitation of the deep biosphere following a large impact, as seen at the Chesapeake impact structure (Figure F8), will shed light on whether peak rings and impactites are an ecological niche for exotic life and thus potentially important habitats for early life on Earth (Kring and Cohen, 2002; Bryce et al., 2015).

\section{Recovery of life}

Immediately after impact, the ocean filling in the crater was likely sterile. We will use cores from the post-impact sedimentary rocks to examine the recolonization of the ocean, including what biota came back first (benthic versus planktic, phytoplankton versus 
Figure F8. Microbial enumerations (log abundance per gram dry weight) through the Chesapeake Bay impact structure, showing a modern-day microbial habitat in the impactites. Modified from Cockell et al. (2009); from Special Papers-Geological Society of America.

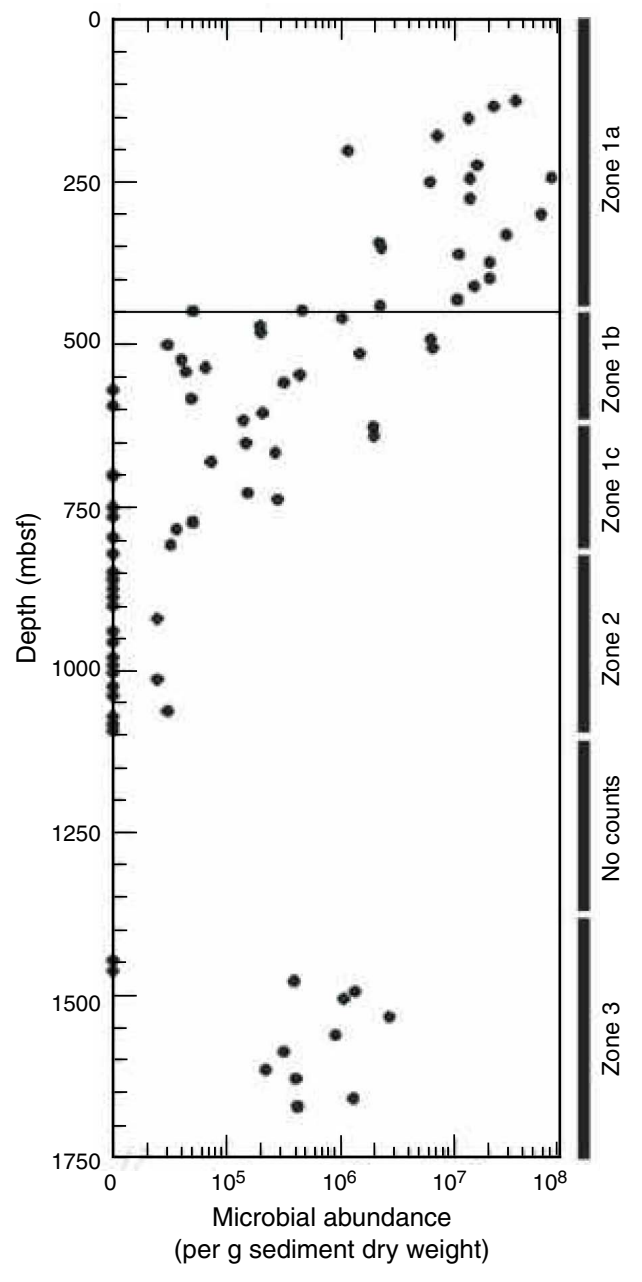

zooplankton, specialists versus generalists), how long it took to return to normal conditions compared to other localities outside the crater, and whether cold-water species occur in the crater, indicating severe cooling due to post-impact environmental change (e.g., Vellekoop et al., 2014). Of interest will be nannoplankton recovery at "ground zero" in comparison to the global response (e.g., Jiang et al., 2010). It is possible that a long-term, impact-initiated hydrothermal circulation system (Abramov and Kring, 2007) caused a delay in local recovery. Did diversity gradually recover with the hardiest taxa appearing first and new species slowly populating the basin as they originated, as in other global sections, or did the whole assemblage return simultaneously once the environment stabilized? Reconstruction of the environment of the earliest Paleocene will be achieved using paleoecology, ichnofacies analysis, major and minor element geochemistry, stable carbon and oxygen isotopes of carbonates, and stable carbon and nitrogen isotopes of sedimentary organic matter. These analyses, which include proxies for biologic productivity and redox conditions, will be used to reconstruct the paleoceanographic conditions in the basin after impact and provide clues to when normal marine carbon and nitrogen cycling were restored. Study of biomarkers at the molecular level (high-pressure liquid chromatography [HPLC] and liquid chromatography-mass spectrometry [LC-MS]) and pigments (chlorophylls, bacteriochlo- rophylls, and their degradation products) from photosynthetic organisms (algae and photosynthetic bacteria) may indicate changes in and evolution of photosynthetic organism populations after impact.

It is expected that both marine and terrestrial organic matter have accumulated in the post-impact sedimentary rock and that the paired stratigraphic analysis of the paleome and lipid biomarkers and their isotopic compositions using precisely dated core material will provide detailed insights into post-impact environmental conditions and the recovery and evolution of surface and deep subsurface life (Coolen et al., 2007, 2013). Of interest is the ocean chemistry and temperature immediately following the impact and any indicators of climatic recovery. Are there signs of local hydrothermal venting (Zürcher and Kring, 2004), short-term global cooling (Vellekoop et al., 2014), and/or indicators of ocean acidification? How long did it take to return to normal conditions? Oxygen isotope ratios, in particular, may help constrain surface and bottom water temperatures in the immediate post-impact interval. Intrinsic magnetic properties of sediments can be used as a proxy of the relative abundance of biogenic versus detrital fractions in the sediments, and changes in magnetic mineralogy can be attributed to changes in the depositional environment (redox conditions, detrital source, etc.).

\section{Eocene and Paleocene hyperthermals and the PETM transition}

Transient warm events (also called hyperthermals) during the early Paleogene "greenhouse" phase of Earth's climate history provide key insights into the feedbacks in the climate system. The Paleocene to Eocene intervals cored during Expedition 364 are particularly interesting due to the potential to recover the PETM, as well as late Paleocene and early Eocene events (Figure F9). Sedimentary records of many PETM transitions and hyperthermals suffer from poor preservation due to dissolution. The section we recovered at Chicxulub is atypical because it is in a subtropical location and within a semi-isolated basin above the calcium compensation depth (CCD); therefore, carbonate sediment accumulation should have been maintained throughout the Paleocene and Eocene.

Key to understanding any recovered hyperthermal intervals including the PETM will be the documentation of changing paleoceanographic conditions (depth, detrital nutrient input, temperature, and redox state), sedimentary environments, and biological productivity. Biological productivity will be evaluated through analysis of total organic carbon (TOC), stable isotopes from organic matter $(\mathrm{C}, \mathrm{N})$ and carbonates $(\mathrm{C}, \mathrm{O})$, and XRF geochemical analyses to determine concentrations of micronutrients such as $\mathrm{Cu}, \mathrm{Ni}$, and $\mathrm{Zn}$. XRF analyses of redox-sensitive trace metals $(\mathrm{Cr}, \mathrm{Ni}, \mathrm{Mo}, \mathrm{V}$, and $\mathrm{U}$ ) will provide insight into bottom water oxygenation during the PETM and Eocene hyperthermals. High-resolution biostratigraphy and magnetostratigraphy will be used to obtain a robust age model in the post-impact sediment and identify key events in the cored interval, including the hyperthermals and PETM.

Changes in continental weathering during the Paleocene-Eocene transition will be evaluated through studying clay mineralogy and major elements ( $\mathrm{Al}, \mathrm{Si}, \mathrm{Ti}$, and $\mathrm{Zr}$ ). There was an intensified hydrological cycle and warming across the PETM (Zachos et al., 2001), and inputs of kaolinite, illite, palygorskite, and/or sepiolite, as well as major elements related to silicate weathering (Schulte et al., 2011) into sedimentary basins during this period, have been linked to an increase in runoff (John et al., 2012). 
Figure F9. Generalized climate curve for the Cretaceous and Paleogene derived from deep-sea benthic oxygen isotope data (Zachos et al., 1993, 2001). Also shown: Eocene/Oligocene boundary, PETM, K-Pg boundary, midMaastrichtian event (MME), and early Aptian Oceanic Anoxic Event (OAE1a). Modified from the Leg 198 Synthesis (Bralower et al., 2006).

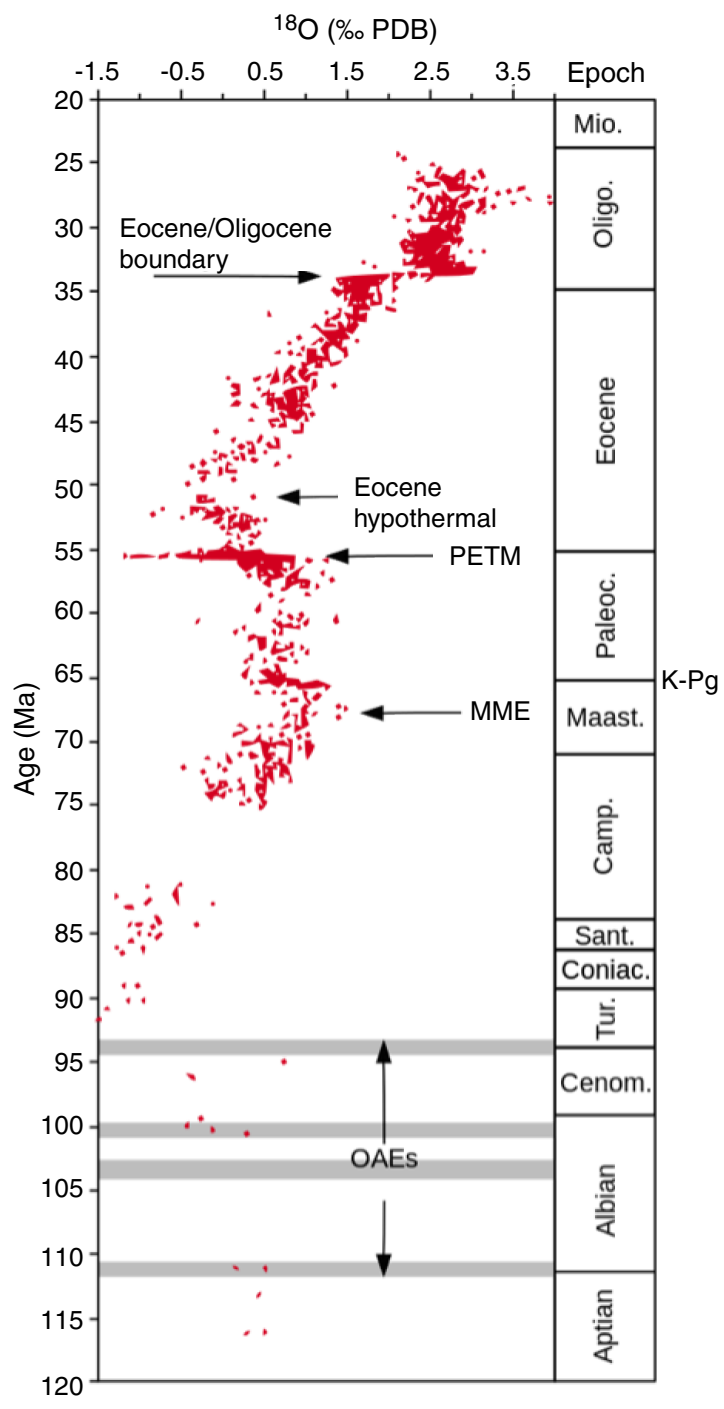

\section{Suevite, impact melt rock, and basement rocks forming the peak ring}

Chicxulub impactites appear to be quite variable, in particular with respect to the amount of anhydrite and the lithology and age of basement clasts (Kettrup et al., 2000; Kring, 2005; UrrutiaFucugauchi et al., 2008). The mineralogical and geochemical characterization of the peak-ring rocks will provide key information on target rock composition (Koeberl et al., 2012). We will also search for an extraterrestrial signature using platinum group element (PGE) analyses and Os and Cr isotopes (Gelinas et al., 2004; Tagle and Hecht, 2006; Trinquier et al., 2006; Goderis et al., 2012; Sato et al., 2013, 2016) to determine whether a measurable fraction of the projectile remains at the impact site or whether most projectile material ends up within the global K-Pg layer (Artemieva and Morgan, 2009). High-resolution ${ }^{40} \mathrm{Ar} /{ }^{39} \mathrm{Ar}$ analyses and electron microscopy on shocked and melted impactites, as well as $\mathrm{U} / \mathrm{Pb}$ dating of zircon and other geo- and thermochronometers, will be used to study their pressure-temperature-time and deformational history and for high- precision dating of the Chicxulub impact. Shock metamorphism of the feldspathic components will be used to investigate how impact processes affect argon retention (Pickersgill et al., 2015). Shock metamorphism and pyrometamorphic indicators for rock-forming minerals will help constrain peak shock pressure and temperature regimes (Grieve et al., 1996; Tomioka et al., 2007; Wittmann et al., 2009; Huber et al., 2011; Rae et al., 2015). Compositional and structural investigations of any intruded dikes will allow assessment of their origin, energy of emplacement, timing, and, for example, discover whether impact melt rock within dikes is more mafic than the impact melt rock in the central crater, as it is in Borehole Yax-1 (Wittmann et al., 2004).

Magnetic susceptibility and paleomagnetic measurements will be used to investigate whether hydrothermal circulation led to the formation of ferromagnetic minerals and chemical remanent magnetization (e.g., Quesnel et al., 2013). These measurements will also allow us to evaluate whether hydrothermal circulation is the source of the strong magnetic anomaly recorded at the surface and whether a component of the natural remanent magnetization (NRM) in peak-ring lithologies is shock induced (Tikoo et al., 2015). We will also investigate detrital remanent magnetizations held by post-impact sedimentary rocks, following previous investigations of Borehole Yax-1 (Rebolledo-Vieyra and Urrutia-Fucugauchi, 2004).

\section{Dust, climatically active gases, and wildfires}

The study of the shock and thermal effects recorded in the carbonate and evaporite impactites will help to more precisely constrain the degassing process of carbonates and evaporates from the Yucatán target rock. Placing constraints on the impact energy with numerical simulations and on the lithology, shock state, and porosity of the target rocks is important because these are all critical input parameters for modeling the environmental effects of this impact (Pope et al., 1997; Pierazzo et al., 2003). Solid, melted, and vaporized material from the asteroid and target rocks are ejected away from the impact site within an expanding plume (Figure F10), and the mass, velocity, and composition of these ejecta are dependent on impact angle (Artemieva and Morgan, 2009; Morgan et al., 2013). The duration and strength of the thermal pulse delivered at the Earth's surface by reentering ejecta varies with direction and distance from Chicxulub (Morgan et al., 2013), and this variation affects the likelihood of ignition of flora (Belcher et al., 2015). Geophysical and drill core data, as well as 3-D numerical simulations of the impact, will be used to constrain impact angle and direction and to better constrain the intensity of the thermal pulse around the globe.

\section{Post-impact sedimentary rocks, including resurge and/or tsunami deposits}

Was the peak ring (being a topographic high) protected from resurge deposits? Or is it covered by wash-back deposits such as multitiered, coarse-grained, reworked suevites or cross-bedded sedimentary rocks overlain by a K-Pg Ir-rich layer? What is the history of peak-ring burial within the impact basin into the Eocene?

We will investigate the uppermost peak-ring deposits to determine the events immediately post-impact. There may be evidence of repeated tsunami and seiche surges, as observed at Brazos River, Texas (USA), in the form of several distinct graded layers (Schulte et al., 2006; Vellekoop et al., 2014).

We will also use drilling, a vertical seismic profile (VSP) experiment, and other logging data to identify the borehole depths and core-based lithologic contrasts that generate reflections in our seis- 
Figure F10. Simulation of ejecta plume from Chicxulub $35 \mathrm{~s}$ after impact. Green = basement, gray $=$ projectile and sediments, light blue = atmosphere, dark blue = mantle. Modified from Artemieva and Morgan (2009); from lcarus.

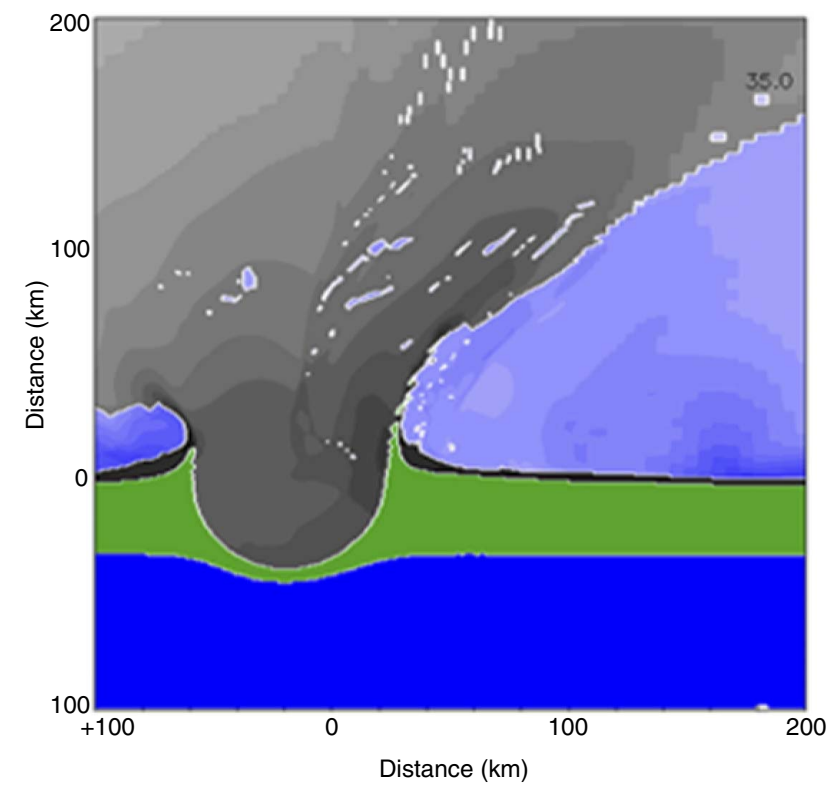

mic data (Figures F2, F3, F4). With this core-log-seismic mapping, we can identify the stratigraphic age of reflectors and map horizons across the impact basin using the extensive suite of seismic reflection data acquired in 1996 and 2005. Sedimentological and stratigraphic data are key to understanding the paleoceanographic and sea level history across this impact basin (Whalen et al., 2013). Detailed biostratigraphic and sedimentologic studies including analysis of grain size, mineralogy, sedimentary structures, and ichnofabric using the cores and X-ray computed tomography (CT) scans will be crucial in documenting the post-impact sedimentary history. Radioisotopic dating of ash layers in the post-impact section will be used along with magnetostratigraphic and biostratigraphic analyses to investigate the volcanic history of this portion of the Gulf of México and to additionally constrain the post-impact age model. Drill core data will be used to groundtruth seismic reflectors, which can be tracked into adjacent deep-water sections to help understand the nature of lower Cenozoic sequences in the Gulf of México, which are difficult to date due to the lack of publicly available scientific cores. This mapping into the broader Gulf of México will enable testing of models for large-scale basin margin collapse caused by impact generated earthquakes and tsunami (Sanford et al., 2016).

\section{Chronology of peak-ring rocks and impact lithologies}

Of key interest is the age of the Chicxulub impact and the resulting K-Pg boundary deposits that it caused (Schulte et al., 2010; Renne et al., 2013). Therefore, a goal of the expedition was to determine the ages of impact lithologies and impact melt rock and any reset ages on uplifted target rocks at the impact site. This work will be accomplished through Ar-Ar and U-Pb ages on impact glasses and $\mathrm{Ar}$-Ar dating of feldspars paired with $\mathrm{U}-\mathrm{Pb}$ dating of zircons. Additionally, a range of geo- and thermochronometers will be explored within the drilled samples to investigate pressure-temperature-time paths within the peak ring.

\section{Petrophysical groundtruth and geophysical integration}

Wireline logging and petrophysical measurements on the core will be used to groundtruth geophysical models (gravity, magnetic, refraction, and magnetotelluric data) and integrate them with 2-D and 3-D seismic velocity data. Core- and borehole-based measurements will be critical to improving our understanding of crater structure away from the drill hole, in particular onshore where deep borehole and seismic data are sparse to nonexistent. Drilling will allow us to address questions such as what is the cause of the strong magnetic anomaly recorded at the surface, and what is the cause of the low seismic velocities and densities within the peak ring (are these fractured deep-crustal basement rocks, megabreccia, or some other material), and is the thin (100-150 m thick) layer of low-velocity rocks forming the uppermost lithology of the peak ring composed of polymictic breccia and/or impact melt rock? We will also use borehole imaging to constrain dips within the peak-ring stratigraphy to test for overturning during emplacement and verify whether the dips are consistent with the observed inward-dipping reflectors and region of lowered velocities visible on seismic data. Magnetic properties of the peak-ring rocks can be used to investigate the sources of magnetic anomalies throughout the crater and as a tool to correlate between onshore boreholes and offshore Site M0077.

\section{Operational strategy}

Expedition 364 was drilled using a Mission Specific Platform due to the relatively deep target depth (1500 m drilling depth below seafloor [DSF]) and shallow-water location $(19.8 \mathrm{~m})$. In order to meet the scientific aims, an Atlas Copco T3WDH mining rig was cantilevered from the bow of the jack-up platform, the L/B Myrtle. The vessel was contracted from Montco Offshore with drilling services provided by Drilling Observation and Sampling of the Earths Continental Crust (DOSECC).

The downhole logging program was managed by the European Petrophysics Consortium (EPC). The University of Montpellier was subcontracted for wireline ultraslimline logging, and the University of Alberta (Canada) and the University of Texas at Austin (USA) were contracted to carry out VSP measurements.

The first phase of mobilization began on 12 March 2016 in Fourchon, Louisiana (USA). The vessel transited to the drill site (with refueling and weather delays), arriving on station on 5 April. The final mobilization was completed on station, and the offshore operational phase began with open-hole drilling on 8 April. Operations continued for 48 days, culminating on 26 May. Following a final phase of downhole logging, the vessel returned to Progreso, México, before continuing transit back to Fourchon for full demobilization.

A single hole was drilled. A series of drill strings of reducing diameters were utilized in order to maximize the likelihood of reaching the target depth. The borehole configuration comprises the following components (Figure F11):

- Open-hole drilling:

- $12 \frac{1}{4}$ inch open-hole drilling from the seabed to $15.5 \mathrm{~m}$ DSF.

- 95/8 inch casing and cementation to $15.5 \mathrm{~m}$ DSF.

- 77/8 inch open-hole drilling from $15.5 \mathrm{~m}$ to $503.6 \mathrm{~m}$ DSF.

- $65 / 8$ inch casing and cementing to $503.6 \mathrm{~m}$.

- The base of the hole was advanced to $505.7 \mathrm{~m}$ DSF while clearing cement and debris from the bottom of the hole. 
- Coring:

- Coring with oversize PQ3 (outer diameter [OD] 5.875 inches [149.225 mm]) from 505.7 to $701.64 \mathrm{~m} \mathrm{DSF}$, producing an $\sim 83 \mathrm{~mm}$ diameter core.

- $5 \frac{1}{2}$ inch casing was set to $701 \mathrm{~m}$ DSF before changing the core barrel and bit size.

- Coring with PQ3 (OD 4.827 inches [122.6058 mm]) from $701.64 \mathrm{~m}$ DSF to the base of the hole at $1334.69 \mathrm{~m} \mathrm{DSF}$, maintaining $\sim 83 \mathrm{~mm}$ diameter cores.

Table T1 summarizes hole details and recovery.

The downhole logging strategy involved a similar stepwise approach to ensure logs were collected from the maximum interval

Figure F11. Expedition 364 drilling strategy.

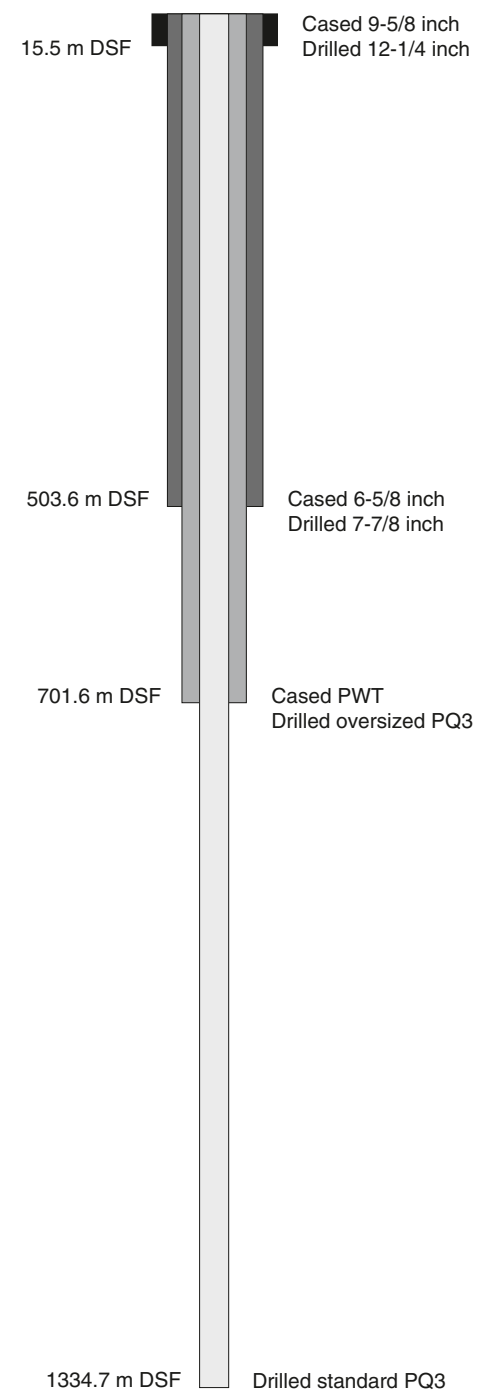

possible. Details of the downhole logging program are summarized in Downhole logging.

During the operational phase of Expedition 364 from 5 April to 30 May 2016, 2.67\% of the operations time was spent mobilizing, $0.22 \%$ in transit, and $11.48 \%$ on downtime due to equipment. The remaining $85.67 \%$ of the offshore phase was for drilling, coring, and downhole logging operations.

\section{Principal results}

Open-hole drilling occurred from the seabed to 500 m DSF, and core was recovered between 505.70 and 1334.69 mbsf. Attempts to recover drilling cuttings from the open-hole section were largely unsuccessful due to loss of the drilling fluid into the formation. In the upper cores, the Post-Impact Sedimentary Rocks interval was recovered between 505.70 and 617.33 mbsf. The Upper Peak Ring rocks recovered were composed of suevite above clast-poor impact melt rock from 617.33 to 747.02 mbsf. This interval overlies Lower Peak Ring shocked granitoids intruded by pre-impact dikes as well as suevite and impact melt rock between 747.02 and 1334.69 mbsf.

Results are divided into four intervals that reflect the key lithological (Figure F12) and structural sequences encountered in Hole M0077A:

- Open Hole: 0-505.70 m DSF

- Post-Impact Sedimentary Rocks: Core 1R to Section 40R-1, $109.4 \mathrm{~cm}$ (505.70-617.28 mbsf)

- Upper Peak Ring (suevite and impact melt rock): Sections 40R-1, $109.4 \mathrm{~cm}$, to $95 \mathrm{R}-3,117 \mathrm{~cm}(617.33-747.02 \mathrm{mbsf})$

- Lower Peak Ring (granitoids, pre-impact dikes, suevite, and impact melt rock): Section 95R-3, $117 \mathrm{~cm}$, through Core 303R (747.02-1334.69 mbsf)

The divisions chosen here are based on observations of core and logging data only. These intervals do not represent the precise locations of lithologic boundaries within the core.

\section{Lithostratigraphy}

\section{Lithostratigraphy and computed tomography facies}

\section{Post-Impact Sedimentary Rocks}

The Post-Impact Sedimentary Rocks interval contains a diverse suite of lithologies, including claystone, black shale, dark marlstone/claystone, marlstone, siltstone, and limestone divided into wackestone, packstone, and grainstone. Most lithologies are dominantly fine grained (clay to silt sized), except for local grainstones that contain clasts that are dominantly sand sized. Most lithologies have examples of planar to wavy laminated textures with ichnofabric indexes of 1 to 2 or are bedded at the centimeter scale. Thicker bedded units are dominantly bioturbated with ichnofabric indices of 3 to 5. Cyclic or rhythmic arrangement of lithologies is common, with cycles typically grading upward from dark marlstone/claystone

Table T1. Hole M0077A summary.Note that percent recovery exceeds $100 \%$ due to opening of fractures resulting in the amount of core recovered exceeding that drilled. Download table in CSV format.

\begin{tabular}{ccccccccc}
\hline Hole & Location & $\begin{array}{c}\text { Water } \\
\text { depth }(\mathrm{m})\end{array}$ & $\begin{array}{c}\text { Cores } \\
(N)\end{array}$ & $\begin{array}{c}\text { Interval } \\
\text { cored }(\mathrm{m})\end{array}$ & $\begin{array}{c}\text { Interval open } \\
\text { holed }(\mathrm{m})\end{array}$ & $\begin{array}{c}\text { Penetration } \\
\text { depth }(\mathrm{m})\end{array}$ & $\begin{array}{c}\text { Core } \\
\text { recovered } \\
(\mathrm{m})\end{array}$ & $\begin{array}{c}\text { Cocevery } \\
(\%)\end{array}$ \\
\hline M0077A & $2127.009^{\prime} \mathrm{N}, 8956.962^{\prime} \mathrm{W}$ & 19.80 & 303 & 828.99 & 505.7 & 1334.69 & 839.51 & 101.27 \\
\hline
\end{tabular}


Figure F12. Lithology summary, Hole M0077A.

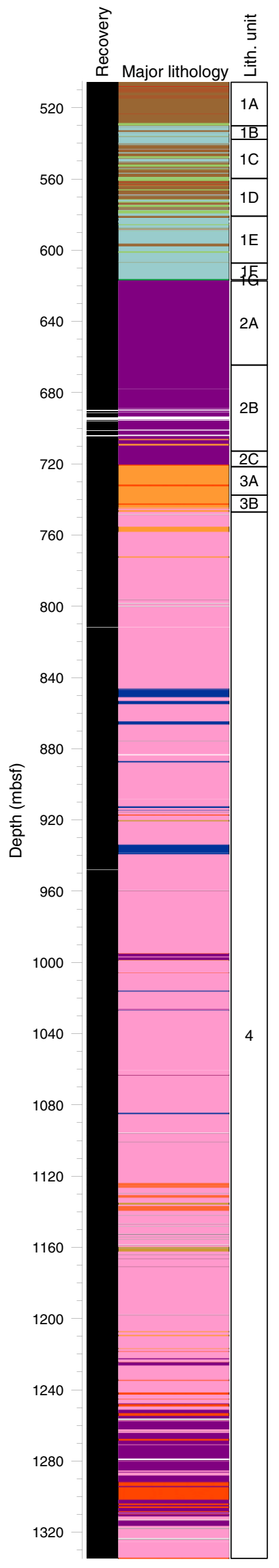

through marlstone and wackestone and/or packstone. Except locally (i.e., Section 37R-1), grainstones are thin, laminated, or crosslaminated packages intercalated with finer grained facies.

The relative distribution and proportions of different lithologies, as well as specific surfaces indicating erosional truncation of underlying facies or abrupt change in lithology, were used to divide the Post-Impact Sedimentary Rocks interval into different lithostratigraphic Subunits (1A-1G; Table T2). Most subunits are between 20 and $27 \mathrm{~m}$ thick, except for Subunits $1 \mathrm{~B}, 1 \mathrm{~F}$, and 1G, which are all less than $10 \mathrm{~m}$ thick. Subunit $1 \mathrm{~A}$ is dominated by dark marlstone/claystone. Subunit $1 \mathrm{~B}$ is mainly limestone with intercalated marlstone and dark marlstone/claystone. Subunits $1 \mathrm{C}$ and $1 \mathrm{D}$ are largely composed of dark marlstone/claystone but also contain marlstone and limestone. Subunits $1 \mathrm{E}$ and $1 \mathrm{~F}$ are primarily wackestone and packstone. Subunits $1 \mathrm{D}$ and $1 \mathrm{E}$ are the only units that contain black shale. All units have sporadic rare to common beds of bluish claystone that were likely deposited as volcanic ash. Subunit $1 \mathrm{G}$ is very thin $(<1 \mathrm{~m})$ and lithologically unusual as a fining-upward calcareous siltstone dominated by thin rhythmic alternations of darker and lighter colored laminae or beds that form the base of the post-impact sedimentary rock succession. The inclusion of greenish clasts of glass in the lower part of the unit signals the transition to the underlying suevite of Subunit 2A (Table T2).

\section{Peak ring}

From Section 40R-1, $109.4 \mathrm{~cm}$, to the end of the drill cores at Section 303R-3, $56 \mathrm{~cm}$, a succession of Chicxulub crater impactites occur, comprising suevite, impact melt rock, and shocked basement rocks.

The Upper Peak Ring interval consists of an impactite sequence from Section 40R-1, $109.4 \mathrm{~cm}$, to Section $87 \mathrm{R}-2,90 \mathrm{~cm}$, and is divided into Units 2 and 3 (Table T2). Unit 2 extends to Section 87R$2,90 \mathrm{~cm}$, and contains $104 \mathrm{~m}$ of suevite with impact melt clasts, as well as lithic clasts from the carbonate platform and basement ranging in size from submillimeter to over $25 \mathrm{~cm}$. Clasts are subangular to subrounded. The suevite matrix is fine-grained, micritic carbonate. Subunit $2 \mathrm{~A}$ is characterized by repeated fining-upward or coarsening features in the suevite with clast sizes $<2 \mathrm{~cm}$. The transition to Subunit 2B in Section 55R-3, $11 \mathrm{~cm}$, is the lowest erosional contact observed in Unit 2. Subunit $2 \mathrm{~B}$ consists of a single $48 \mathrm{~m}$ fining-upward succession. Subunit $2 \mathrm{C}$ begins at Section $83 \mathrm{R}-1,75 \mathrm{~cm}$, with a gradational change to a $\sim 9 \mathrm{~m}$ thick, dark brown suevite matrix with very poorly sorted angular to subangular clasts.

Unit 3 begins at Section $87 \mathrm{R}-2,90 \mathrm{~cm}$, and is composed of impact melt rock with rare $(<25 \%)$ clasts. It is divided into two subunits. Subunit 3A is characterized by a $16 \mathrm{~m}$ thick mixture of green and black melt rock. The green material sometimes forms a matrix with angular fragments of black melt rock and can be intimately intermixed with black melt rock, forming schlieren of green material. Within the black melt rock, centimeter- to decimeter-sized clasts of target material are found composed of metamorphic and igneous target lithologies, including decimeter-sized clasts of granodiorite and gneiss. Subunit 3B is a $\sim 9.5 \mathrm{~m}$ thick coherent black melt rock interval that begins at Section 92R-3, $17 \mathrm{~cm}$. Clasts are composed of metamorphic and igneous target lithologies, but the subunit lacks visible clasts of sedimentary lithologies. Clasts of granitoids dominate and increase in abundance toward the base of the subunit and are up to $42 \mathrm{~cm}$ in diameter.

Beneath Section 95R-3, $117 \mathrm{~cm}$, the Lower Peak Ring interval recovered at Site M0077 includes a long succession of felsic basement rocks of granitoid composition (Unit 4). Petrographically, these rocks are characterized chiefly by coarse-grained granite to 
Table T2. Lithostratigraphic units, Hole M0077A. Determined using Corelyzer. Boundary is defined at the average depth if it is inclined. Bottom of Unit 3B is defined as first occurrence of granitic rocks. Download table in CSV format.

\begin{tabular}{|c|c|c|c|c|c|c|}
\hline Unit & $\begin{array}{l}\text { Top } \\
\text { depth } \\
\text { (mbsf) }\end{array}$ & $\begin{array}{l}\text { Bottom } \\
\text { depth } \\
\text { (mbsf) }\end{array}$ & $\begin{array}{l}\text { Top core, section, } \\
\text { interval }(\mathrm{cm})\end{array}$ & $\begin{array}{l}\text { Bottom core, section, } \\
\text { interval }(\mathrm{cm})\end{array}$ & $\begin{array}{l}\text { Thickness } \\
(\mathrm{m})\end{array}$ & Top boundary definition \\
\hline $1 \mathrm{~A}$ & 505.70 & 530.18 & $1 \mathrm{R}-1,0$ & $1 \mathrm{R}-2,116.8$ & 24.48 & Top of core \\
\hline $1 B$ & 530.18 & 537.80 & $11 \mathrm{R}-2,116.8$ & 14R-1, 86.40 & 7.62 & Sharp erosional contact that truncates underlying thin grainstone \\
\hline $1 C$ & 537.80 & 559.75 & 14R-1, 86.40 & $21 \mathrm{R}-1,146.20$ & 21.95 & Erosional contact that truncates underlying dark marlstone/claystone \\
\hline 1D & 559.75 & 580.89 & $21 \mathrm{R}-1,146.20$ & $28 \mathrm{R}-1,125.20$ & 21.14 & $\begin{array}{l}\text { Gradational contact designated as the last dark millimeter-scale } \\
\text { marlstone/limestone }\end{array}$ \\
\hline $1 \mathrm{E}$ & 580.89 & 607.27 & $28 \mathrm{R}-1,125.20$ & $37 \mathrm{R}-1,25.60$ & 26.38 & Change to bluish colored marlstones at the top \\
\hline $1 \mathrm{~F}$ & 607.27 & 616.58 & $37 \mathrm{R}-1,25.60$ & $40 \mathrm{R}-1,34.20$ & 9.31 & Top of a prominent carbonate cemented surface \\
\hline $1 G$ & 616.58 & 617.33 & $40 \mathrm{R}-1,34.20$ & 40R-1, 109.4 & 0.75 & Contact between light green claystone and underlying brown siltstone \\
\hline $2 \mathrm{~A}$ & 617.33 & 664.52 & 40R-1, 109.4 & $55 \mathrm{R}-3,11$ & 47.19 & Sharp stylolitized contact at top of suevite \\
\hline 2B & 664.52 & 712.84 & $55 \mathrm{R}-3,11$ & $83 \mathrm{R}-1,75$ & 48.32 & Erosional contact at Section 55R-3, 6-16 cm \\
\hline $2 \mathrm{C}$ & 712.84 & 721.61 & $83 R-1,75$ & $87 R-2,90$ & 8.77 & $\begin{array}{l}\text { Gradational change from mid-brown suevite matrix with subangular to } \\
\text { subrounded clasts to dark-brown suevite matrix with angular to } \\
\text { subangular clasts }\end{array}$ \\
\hline $3 \mathrm{~A}$ & 721.61 & 737.56 & $87 \mathrm{R}-2,90$ & $92 \mathrm{R}-3,17$ & 15.95 & First occurrence of massive black melt rock with green schlieren \\
\hline 3B & 737.56 & 747.02 & $92 \mathrm{R}-3,17$ & $95 \mathrm{R}-3,117$ & 9.46 & $\begin{array}{l}\text { Last occurrence of massive black melt rock with } \\
\text { green schlieren }\end{array}$ \\
\hline 4 & 747.02 & 1334.69 & $95 \mathrm{R}-3,117$ & $303 R-3,51$ & 587.67 & First occurrence of granitoid larger than $1 \mathrm{~m}$ \\
\hline
\end{tabular}

syenite hosting aplite and pegmatite dikes. Moreover, granitoid rocks are intruded by three types of subvolcanic dikes or dike swarms, including felsite, dacite, and diabase/dolerite. Petrographic analysis shows that this suite of basement rocks is pervasively shocked, with quartz and feldspar grains displaying planar deformation features throughout the entire unit. Granitoids also show localized zones of pervasive shearing and deformation, with notable millimeter- to centimeter-thick cataclastic bands and microbrittle foliation.

Granitoid basement rocks host several smaller bodies of suevite and impact melt rock ( $15 \mathrm{~cm}$ to $4 \mathrm{~m}$ thick). An approximately $70 \mathrm{~m}$ thick interval of suevite and impact melt rock interspersed with granitoids occurs at 1245-1316 mbsf (Cores 265R-298R). The lower part of this unit is dominated by suevite, occasional clast-rich (>25\%) impact melt rock, and only a few decimeter- to meter-scale intercalations of granite. Flow banding occurs in both the impact melt rock and suevite. Clasts are melt rock fragments, granitoids, and other basement lithologies. Clast composition is characterized by a notable lack of carbonates and other sedimentary rocks compared to the suevite and impact melt rock in the Upper Peak Ring interval. Granitic rocks were cored in Cores 298R-303R, and the final sections (303R-2 and 303R-3) of the borehole consist of a $78 \mathrm{~cm}$ thick polymict breccia mingled with impact melt rock.

\section{CT facies}

CT facies were described throughout the hole. Distinctions between different CT facies were made on the basis of CT number, uncalibrated bulk density $\left(\rho_{\mathrm{b}}\right)$, uncalibrated effective atomic number $\left(\mathrm{Z}_{\text {eff }}\right)$, and common textures. In general, CT facies show a good match with the lithologic boundaries and lithostratigraphic units identified during visual core description. CT facies are described in the context of a relative, qualitative comparison of higher and lower CT number. Similar lithologies usually display similar CT number values, which are represented by a grayscale color scheme (white = high; black = low). In addition, CT number was compared to images of $\rho_{b}$ and $Z_{\text {eff. }}$

\section{Post-Impact Sedimentary Rocks}

The CT scans of representative lithologies and each subunit from the Post-Impact Sedimentary Rock interval were described.
Marlstone and dark claystone/marlstone lithologies are associated with light gray and dark gray intervals that display mainly low $\rho_{\mathrm{b}}$ and high $\mathrm{Z}_{\text {eff }}$ values. Overall, the reoccurring, relatively thin claystone layers are represented by black $C T$ intervals that correspond to relatively low $\rho_{b}$ and $Z_{\text {eff }}$ values. The wackestones and packstones of the limestone lithologies are mainly associated with light to dark gray and black intervals that reflect a broad spectrum of $\rho_{b}$ and $Z_{\text {eff }}$ values. The grainstone lithology presents itself uniformly as a light gray interval associated with high $\rho_{\mathrm{b}}$ and $\mathrm{Z}_{\text {eff }}$ values.

A CT facies is also defined for the lithostratigraphic units (Subunits $1 A-1 G)$. Subunits $1 A-1 C$ show light gray, dark gray, and black intervals that are associated with high $Z_{\text {eff }}$ values and low $\rho_{b}$ (Subunits $1 \mathrm{~A}$ and $1 \mathrm{C}$ ) or relatively high $\rho_{\mathrm{b}}$ values (Subunit 1B). Subunit $1 \mathrm{D}$ is represented by the same color scheme, but the black and white intervals increase in thickness. The $\rho_{\mathrm{b}}$ and $\mathrm{Z}_{\text {eff }}$, values vary depending on the represented lithology (e.g., interbedded marlstones). Subunits $1 \mathrm{E}$ and $1 \mathrm{~F}$ consist predominantly of one light gray CT interval with a few thin dark gray to black areas. The light gray CT interval can be correlated with high but also low $\mathrm{Z}_{\text {eff }}$ and quite variable density values. Subunit $1 \mathrm{G}$ is represented by light to dark gray intervals that are overall associated with relatively high $\rho_{\mathrm{b}}$ and high $\mathrm{Z}_{\text {eff }}$

\section{Upper Peak Ring}

The subunits of Units 2 and 3, divided by visual core description alone, can be clearly seen in the CT data. Additionally, certain subunits (e.g., Subunit 2C) have abrupt and unusual changes in CT character within the subunit.

Unit 2 has an overall trend of increasing CT number. Clast size, density, and compositional variation can be clearly discerned using the CT data. The increase in clast size with depth in the suevite is reflected by an increase in variability of the average $\mathrm{CT}$ number with depth.

Unit 3 marks a slight drop in average CT number compared to Subunit $2 \mathrm{C}$, and $\mathrm{CT}$ numbers remain constant, with some variability, through Subunits 3A and 3B. Texturally, Subunits 3A and 3B are very distinct in the CT data. Subunit $3 \mathrm{~A}$ has a fluidal texture of intermixed light gray and dark gray material, whereas Subunit 3B is considerably more homogeneous and contains occasional clasts. 
Lower Peak Ring

CT facies for Unit 4 were described during visual core description. There are several CT facies within Unit 4, all linked to the described lithology. In general, all of the lithologies within the lower peak ring interval are easily distinguished on the basis of CT number, $\rho_{b}, Z_{\text {eff }}$, and texture.

Granitoids are easily identified in the CT data by their distinctive texture and the individual textures of the constituent minerals. Deformation of the granitoids generally corresponds to low $\rho_{b}$ regions of the rocks. Pre-impact dikes are generally fine grained (although occasionally porphyritic); nonetheless, each of these units can be distinguished based on their CT number, $\rho_{b}$, and $Z_{\text {eff. }}$ The suevite and impact melt rock within the Lower Peak Ring interval are distinctly different in the CT data from those found in the Upper Peak Ring interval, and this difference is expressed primarily by their CT textures. In both locations, the suevite and impact melt rock are easily distinguished from each other by the higher $\rho_{b}$ and $\mathrm{Z}_{\text {eff }}$ of the impact melt rock.

\section{Biostratigraphy}

Seventeen age-diagnostic biostratigraphic datums were identified in the Post-Impact Sedimentary Rocks interval at Site M0077, ranging from the middle Eocene to the base of the Paleocene. The Eocene section ranges from planktic foraminifer Zone E7b to E5 and calcareous nannofossil Zone CP12 to CP10. Eocene sedimentary rocks at Site M0077 are characterized by diverse but variable assemblages of both foraminifers and nannofossils and contain rare to dominant radiolarians, which are often associated with more organic-rich, laminated, and sometimes indurated lithologies that can only be examined in thin section. Benthic foraminifers are relatively rare and comprise an assemblage indicative of middle bathyal depths (500-700 m below sea level).

A set of stacked unconformities spanning Sections 36R-4 through 37R-1 ( 606.5-607.5 mbsf) separate the Paleocene and Eocene sections and include several partial intervals of the upper $\mathrm{Pa}$ leocene (including sedimentary rocks spanning the PETM; nannofossil Zone CP8). The lower Paleocene appears to be complete and ranges from planktic foraminifer Zone P3b to P $\alpha$. Nannofossil zonation is difficult in this interval, and the assemblage is dominated by bloom taxa (e.g., Braarudosphaera). Thoracosphaera, a calcareous dinoflagellate common in early Danian marine records, is very abundant at the base of the post-impact sedimentary rocks. Below Zone P $\alpha$ is a $40 \mathrm{~cm}$ brown siltstone that contains a number of Maastrichtian foraminifers and nannoplankton indicative of impact-related reworking and/or survivors.

Analysis of micro- and macrofossil material in the suevite reveals a diverse assemblage of Cretaceous organisms spanning the Early Cretaceous to the Maastrichtian that are indicative of a number of environments, from shallow-water carbonate platforms to open-shelf pelagic limestones.

\section{Paleomagnetism}

The primary goal of shore-based paleomagnetic studies was to produce a preliminary characterization of the NRM of post-impact sedimentary rocks as well as suevite, impact melt rock, and basement rock within the peak ring of the crater. This objective was achieved by conducting measurements of the NRM and limited alternating field (AF) demagnetization (up to either 15 or $20 \mathrm{mT}$ ) of discrete paleomagnetic samples collected at a minimum frequency of $\sim 1$ sample per $3 \mathrm{~m}$ spanning the entire length of the Expedition 364 core.
The Post-Impact Sedimentary Rocks interval typically had NRM intensities between $1 \times 10^{-10}$ and $8 \times 10^{-9} \mathrm{Am}^{2}$ (for sample volumes of $\sim 12.25 \mathrm{~cm}^{3}$ ). The majority of sedimentary rocks sampled carried a normal polarity magnetic overprint that represents either viscous contamination from the geomagnetic field, drillinginduced magnetization, or some combination thereof. Because this magnetic overprint was not fully removed by AF demagnetization to $15-20 \mathrm{mT}$, the underlying detrital remanent magnetization could not be properly characterized during the Onshore Science Party (OSP). Therefore, attempts to produce a polarity magnetostratigraphy and age model from the Post-Impact Sedimentary Rocks interval will be reserved for postexpedition analyses, when AF demagnetization to field levels higher than $20 \mathrm{mT}$ are permitted.

Upper Peak Ring suevite and impact melt rock within the cores dominantly have NRMs of reversed polarity with a mean inclination value of approximately $-44^{\circ}$. Some suevite samples exhibit a normal polarity magnetization of inclination of approximately $38^{\circ}$ that was likely acquired after the impact. Both of these observations are consistent with prior paleomagnetic investigations of these lithologies in other locations within the Chicxulub crater (Urrutia-Fucugauchi et al., 1994, 2004a; Velasco-Villareal et al., 2011). NRM intensities of the suevite are 3-4 orders of magnitude higher than those of the Post-Impact Sedimentary Rocks interval. The impact melt rock has the highest NRM values in the entire hole, ranging between $\sim 2 \times$ $10^{-5}$ and $\sim 2 \times 10^{-4} \mathrm{Am}^{2}$.

Lower Peak Ring lithologies within the core, which are primarily granitoids intruded by pre-impact dikes, suevite, and impact melt rocks, often have two magnetization components. For the vast majority of basement samples, NRM exhibits negative inclinations that are broadly consistent with the expected inclination at the time of the impact, which took place during reversed polarity Chron 29r. However, after AF demagnetization to $20 \mathrm{mT}$, the residual moment often exhibits a positive inclination. The NRMs of the Lower Peak Ring interval range between $\sim 3 \times 10^{-8}$ and $\sim 4 \times 10^{-5} \mathrm{Am}^{2}$.

\section{Age model}

Seventeen foraminifer and nannoplankton biostratigraphic datums were identified at Site M0077. Paleomagnetic reversal datums are excluded from the age model because of pervasive overprinting. The age-depth plot reveals that sedimentation rates vary widely throughout the section. The Eocene is characterized by high sedimentation rates, averaging $2.3 \mathrm{~cm} / \mathrm{ky}$, whereas the Paleocene is characterized by very low sedimentation rates, averaging 0.22 $\mathrm{cm} / \mathrm{ky}$.

The age model was applied to moisture and density (MAD) dry bulk density data to generate mass accumulation rates for Site M0077, including rates for organic carbon and bulk carbonate deposition. In general, organic carbon accumulation is highest in the younger Eocene section after rising from nearly zero at the base of the Eocene section; carbonate mass accumulation rate is generally high throughout but also increases from the base of the Eocene section to a peak at around $50 \mathrm{Ma}$.

\section{Geochemistry}

Composition and abundance of major, minor, and trace elements, including carbon species and sulfur, and modal mineralogical compositions were measured on 246 samples from Expedition 364 cores. We analyzed 34 samples from the Post-Impact Sedimentary Rocks interval from Cores 3R through 39R, 50 samples from the Upper Peak Ring interval from Cores 40R through 95R, and 163 
samples from the Lower Peak Ring interval from Cores 96R through 303R.

The Post-Impact Sedimentary Rocks interval is dominated by $\mathrm{CaCO}_{3}$, with low $\mathrm{SiO}_{2}$ content expressed as limestones, marlstones, and black shales. The upper post-impact sedimentary rock succession is strongly enriched in organic carbon, which drops to very low concentrations in the lowermost $20 \mathrm{~m}$ of this interval. Details of XRF linescan and UXRF mapping of Section 40R-1 show localized enrichments in $\mathrm{Ni}$ and $\mathrm{Cr}$ near the boundary between limestones and suevite. This boundary also shows a significant change in composition from calcium carbonate-dominated to silicate-dominated lithologies.

The Upper Peak Ring interval exhibits three broad trends based on the geochemical data. The upper trend broadly correlates with Subunit $2 \mathrm{~A}$ and is characterized by relatively constant values. Within Subunit 2B and continuing to Subunit 2C, the geochemical data exhibit higher and more variable elemental concentrations. At the base of this interval, Unit 3, consisting of impact melt rock, has lower carbonate content compared to Unit 2 and shows higher contents of silicate mineral component-derived element concentrations such as $\mathrm{Si}, \mathrm{Al}, \mathrm{K}, \mathrm{Na}, \mathrm{V}, \mathrm{Rb}$, and $\mathrm{Zr}$. Organic carbon contents are very low in the Upper Peak Ring interval as a whole, and total carbon contents are dominated by carbonate carbon.

The Lower Peak Ring interval shows relatively consistent concentrations of major, minor, and trace elements that are dominated by $\mathrm{SiO}_{2}$ but yielded surprisingly low total concentrations. The monotonous granitic chemical character is punctuated throughout the section by intercalations of suevite, impact melt rocks, and pre-impact dike rocks that display variable compositional characteristics. Generally, TOC concentrations are low, as is the case in the Upper Peak Ring interval; however, carbonate-related carbon contents are markedly lower.

\section{Physical properties}

Physical properties measurements were acquired from all cores recovered during Expedition 364. Offshore measurements were taken on whole-round cores (gamma density, electrical resistivity, magnetic susceptibility, and natural gamma ray), and onshore measurements were taken on half-round cores (line-scan images, color reflectance, and thermal conductivity) and on discrete samples $(P$ wave velocity and MAD). Porosity and bulk density were calculated from MAD measurements. Measurements are of good quality overall and reflect the different lithostratigraphic units. $P$-wave velocity, resistivity, magnetic susceptibility, and natural gamma ray were measured both on cores and downhole, and the two data sets correlate well (Figure F13).

In the Post-Impact Sedimentary Rocks interval, porosities decrease with depth, whereas densities and $P$-wave velocities increase. Magnetic susceptibility and natural gamma ray remain relatively constant with low values.

In the Upper Peak Ring interval, $P$-wave velocities and densities are low compared to the overlying Paleocene sedimentary rocks, but both properties increase with depth. An opposite trend is observed for porosities. The transition from post-impact sedimentary rock to peak ring is marked by an abrupt increase in the magnetic susceptibility and natural gamma ray signals.

Finally, in the Lower Peak Ring rocks, $P$-wave velocities increase with depth, with local excursions associated with pre-impact dikes, suevite, and impact melt rock. Overall, densities do not vary much, except for local abrupt changes in the pre-impact dikes or in the lowermost $100 \mathrm{~m}$ of the hole, dominated by suevite and impact melt rock, where values decrease. Porosity values remain constant through the granitoids in the Lower Peak Ring interval and start increasing in the lowermost $100 \mathrm{~m}$ of the hole. Natural gamma ray and magnetic susceptibility are constant overall in the granitoids, with clear positive or negative excursions in the pre-impact dikes, suevites, and impact melt rock.

\section{Downhole logging}

The set of downhole geophysical tools used during Expedition 364 was determined by the scientific objectives, drilling/coring technique, hole conditions, and temperature at the drill site during operations.

Wireline logging and VSP data were acquired in three logging sessions: upper session at $\sim 503 \mathrm{~m}$ DSF, middle session at $\sim 506-$ $699 \mathrm{~m}$ DSF, and lower session at $700-1334 \mathrm{~m}$ DSF. In the lower session, wireline logs were acquired in two steps to avoid an interval of potential hole instability (mud circulation loss zones), identified as the Lower A (939 m DSF to total depth) and Lower B (935-701 m DSF) sessions (Figure F14). The following measurements were acquired in three stages using slimline tools: spectral and total gamma radiation, sonic velocity, acoustic and optical borehole images, electrical resistivity, induction conductivity, magnetic susceptibility, caliper, borehole fluid parameters, and seismic traveltime versus depth from the VSP (Figures F14, F15). Logs were recorded either with standalone logging tools or stackable tools combined into tool strings, which were lowered into the hole after completion of coring operations over a given interval. For the first time in IODP, Expedition 364 deployed stackable slimline probes.

The majority of measurements were performed in open borehole conditions (no casing). The recovery and overall quality of the downhole logging data are good due to the excellent borehole conditions (Figure F14), although some of the logs have a poorer quality in the upper part of the hole $(\sim 0-400 \mathrm{~m}$ wireline log depth below seafloor [WSF]) due to a wider diameter and imperfect borehole conditions. At the scale of the borehole, resistivity and sonic logs are well correlated, as expected. The wireline logs are also in good agreement with the physical properties data acquired both on whole-round cores and discrete samples (Figure F13).

The Post-Impact Sedimentary Rocks interval (0-617.45 m WSF) resistivity from induction log (Res from IL) gives a mean value of $1.2 \Omega \mathrm{m}$, the mean $P$-wave sonic velocity $\left(V_{\mathrm{P}}\right)$ is $2800 \mathrm{~m} / \mathrm{s}$ (below $460 \mathrm{~m}$ WSF), and magnetic susceptibility is low, $<30 \times 10^{-5}$ SI, as expected in carbonates. The character of the gamma ray log changes downhole with a major step in the base level at $\sim 274 \mathrm{~m}$ WSF in the Open Hole interval, with a mean value around 100 API in the overlying interval and of $\sim 30$ API in the lower Open Hole and Post-Impact Sedimentary Rocks intervals. The transition to the Upper Peak Ring interval, found at $617.45 \mathrm{~m} \mathrm{WSF}$, is characterized by a major change in the wireline log properties and illustrated by a sharp downhole decrease in $P$-wave sonic velocities and induction resistivity and an increase in gamma ray at the Post-Impact Sedimentary Rocks/Upper Peak Ring interval boundary.

In the Upper Peak Ring interval (617.45-746.2 m WSF), a clear change in log pattern was observed at $\sim 705.5 \mathrm{~m} \mathrm{WSF}, 17 \mathrm{~m}$ above the top of the impact melt rock found in cores at $\sim 722 \mathrm{mbsf}$. From $\sim 616$ to $705.5 \mathrm{~m}$ WSF, in the suevite, the logs show low variability. The induction resistivity log gives an average value of $\sim 2.6 \Omega \mathrm{m}$. Resistivity and sonic logs follow the same trend. Average sonic $P$-wave velocity is $\sim 2900 \mathrm{~m} / \mathrm{s}$. Magnetic susceptibility is low, below $260 \times$ $10^{-5} \mathrm{SI}$. The gamma ray log shows low variability with an average of 80 API. From $\sim 705.5 \mathrm{~m}$ WSF to the base of the impact melt rock at 
Figure F13. Physical property data, Hole M00077A. MS = magnetic susceptibility, NGR = natural gamma radiation, MSCL = multisensor core logger, VSP = vertical seismic profile.
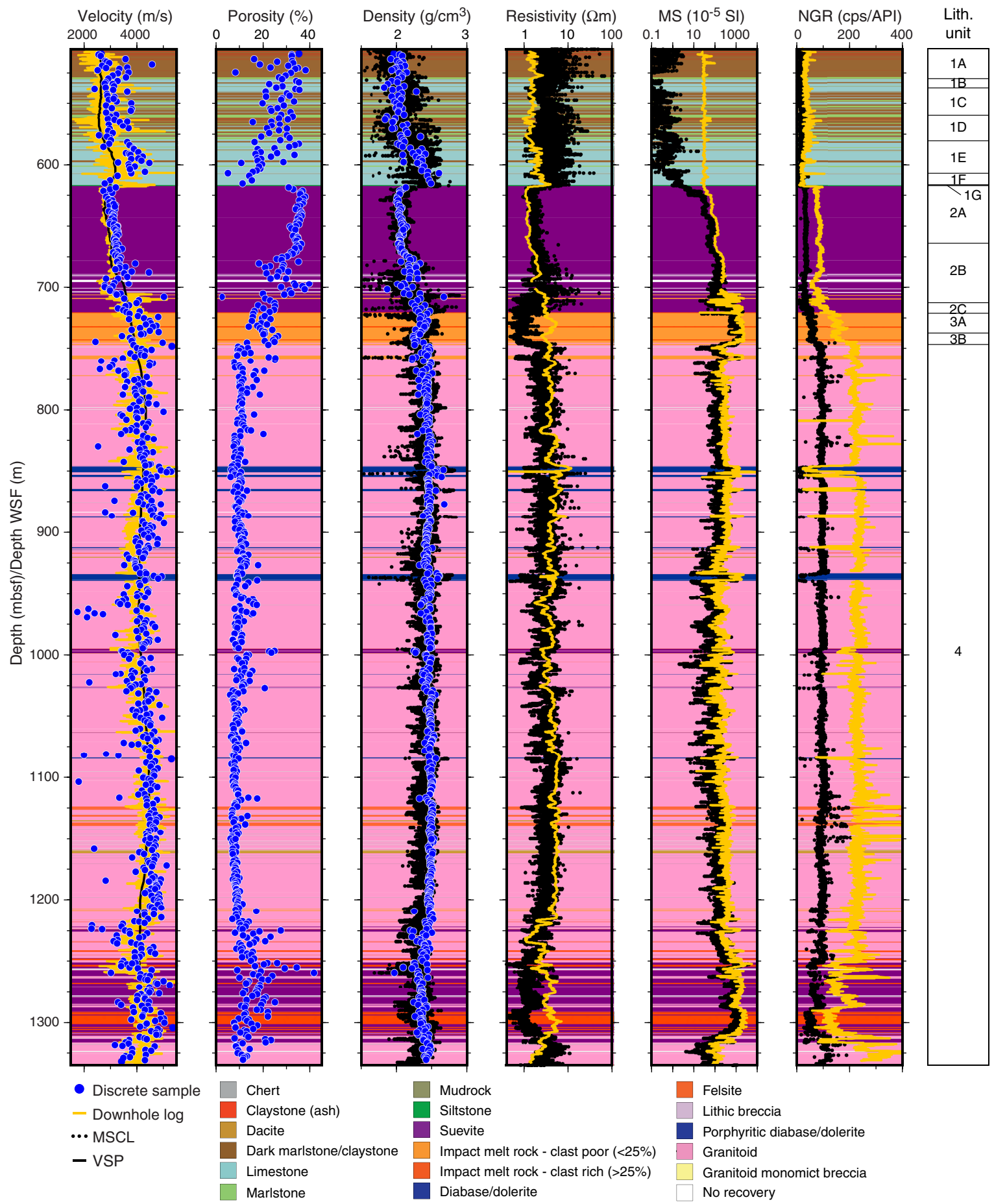

$746.2 \mathrm{~m}$ WSF, the wireline logs show much higher variability compared to the suevite above. The average resistivity is $3.6 \Omega \mathrm{m}$ and the average sonic $P$-wave velocity is $\sim 3900 \mathrm{~m} / \mathrm{s}, \sim 1,000 \mathrm{~m} / \mathrm{s}$ higher than the suevite above. Magnetic susceptibility is high with an average of $1000 \times 10^{-5} \mathrm{SI}$. The gamma ray log shows values ranging between 32 and 260 API. The contact between the impact melt rock of the Upper Peak Ring interval and the granitoids of the Lower Peak Ring interval is found at $746.2 \mathrm{~m} \mathrm{WSF}$ and marked on the wireline logs by

a sharp decrease in magnetic susceptibility and an increase in gamma ray.

In the Lower Peak Ring interval (746.2 to $1334 \mathrm{~m} \mathrm{WSF}$ ), wireline logs are characterized by moderate to low variability. Mean resistivity is $\sim 5 \Omega \mathrm{m}$, and average sonic $P$-wave velocities are $\sim 4100$ $\mathrm{m} / \mathrm{s}$. Magnetic susceptibility is generally low $(<0.002 \mathrm{SI})$, with increasing values in the impact melt rock and suevite intervals. 
Figure F14. Wireline downhole log data, Hole M0077A. Shallow and deep reading resistivity (RLLS and RLLD), resistivity from induction (Res from IL), conductivity (IL), $P$-wave sonic $\left(V_{\mathrm{P}}\right)$, magnetic susceptibility (MSUS), total gamma ray (GR), borehole fluid temperature $\left({ }^{\circ} \mathrm{T}\right.$ FTC; $\mathrm{T}^{\circ}$ Oc), conductivity (Cond FTC; Cond Oc), $\mathrm{pH}$ and redox, gravity and local magnetic field, borehole tilt and azimuth, amplitude and traveltime acoustic images (ABI Amplitude and ABI TT), borehole diameter (CAL and ACCAL), traveltime cross section of the borehole (ABI TT cross section) and optical borehole image (OBI).

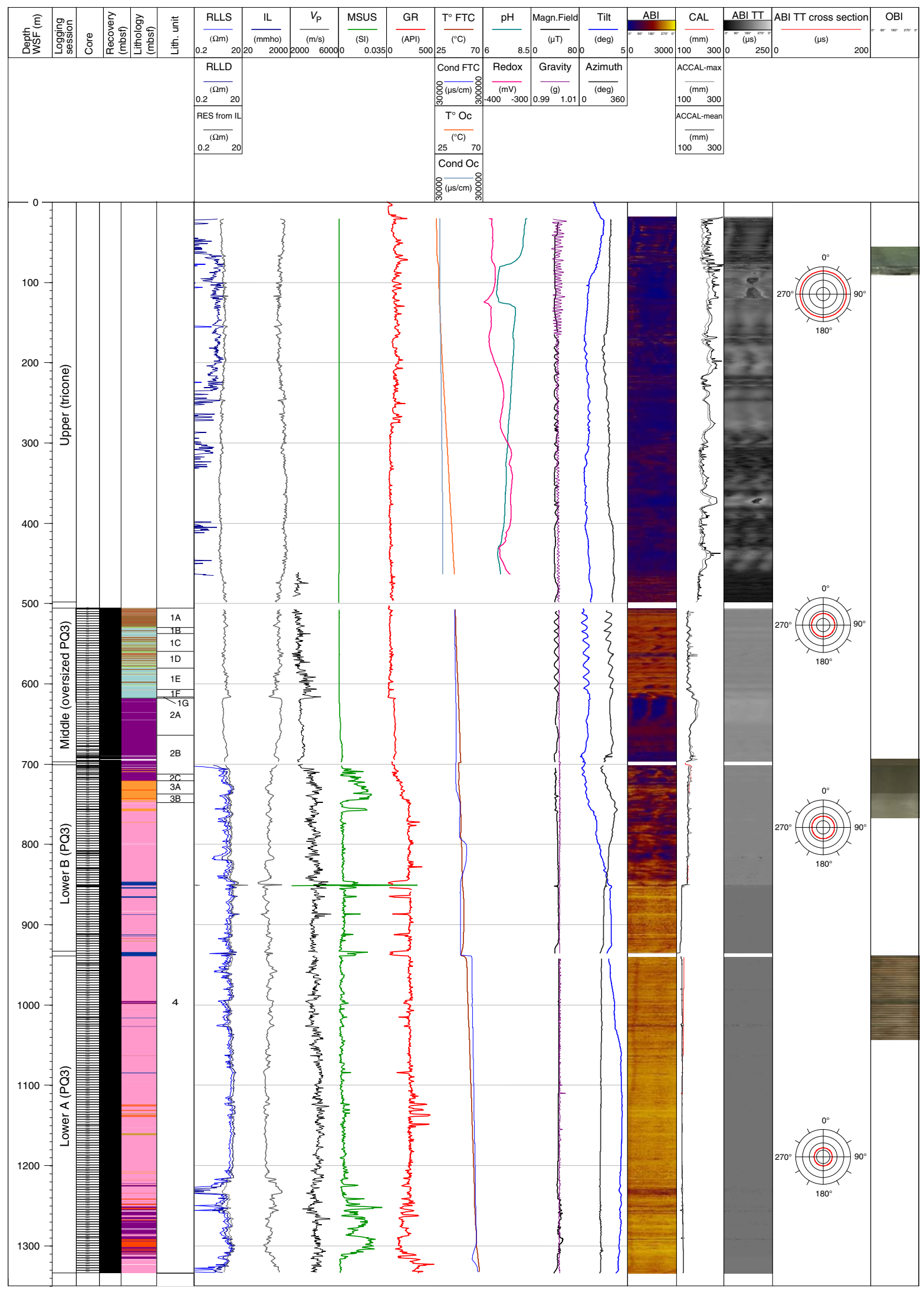


Figure F15. VSP, velocity zones vs. depth regions, and lithostratigraphic units (47.5-1325.0 m WSF), Hole M0077A. Linear best fits are assigned to four manually picked velocity zones (right) and compared to depth regions (left). Lines $=$ upper and lower bounds of $P$-wave velocity using one standard deviation.

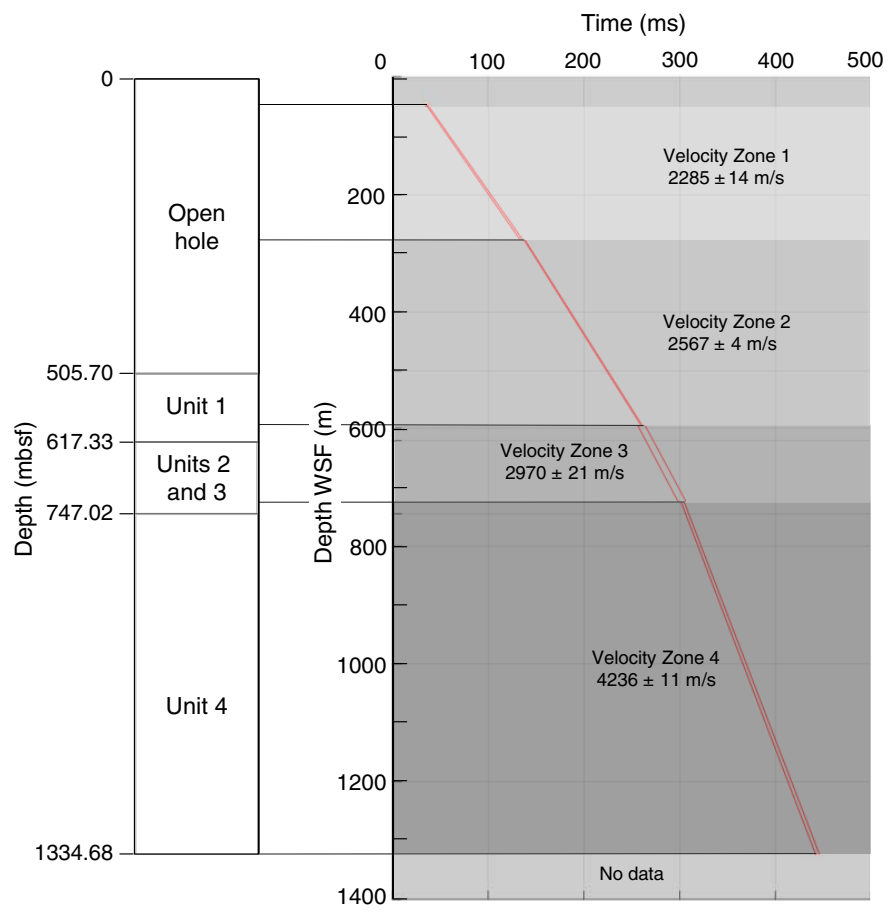

Gamma ray in the granitoids provides consistent values of $\sim 250$ API, whereas higher values ( $>400 \mathrm{API}$ ) were observed in the suevite.

At the borehole scale, the borehole-fluid temperature increases progressively downhole from $\sim 26^{\circ} \mathrm{C}$ to $66.5^{\circ} \mathrm{C}$ at the base of the hole, and the borehole fluid conductivity ranges from 55,000 to $240,000 \mu \mathrm{S} / \mathrm{cm}$. The measurements were acquired in several phases shortly after drilling; fluid parameter logs should therefore only be used qualitatively. The borehole-fluid temperature likely reflects a minimum value for the in situ temperature of the formation, whereas borehole conductivity is also affected by recent drilling operations and the presence of drill mud and seawater in the hole. Acoustic borehole images are mostly of good quality and should allow reorientation of the majority of cores with respect to magnetic north. Figure F16 illustrates the deviation of Hole M0077A.

The three-component VSP is characterized by four major velocity zones (Figure F15). In the Post-Impact Sedimentary Rocks interval, the boundary between Zones 1 and 2 is marked by a $300 \mathrm{~m} / \mathrm{s}$ increase in velocity, and an increase in velocity $(400 \mathrm{~m} / \mathrm{s})$ is seen at $595 \mathrm{~m}$ WSF.

\section{Microbiology}

Rock samples from every 3 to $9 \mathrm{~m}$ within the Post-Impact Sedimentary Rocks interval and every $9 \mathrm{~m}$ within the Upper and Lower Peak Ring intervals were obtained aseptically directly upon coring. These samples were prepared for anaerobic cultivation and cell enumeration as well as for cultivation-independent metagenomic taxonomic and functional diversity profiling.

Figure F16. Borehole deviation, Hole M0077A. A. True vertical depth. B. North and east direction of the borehole path.

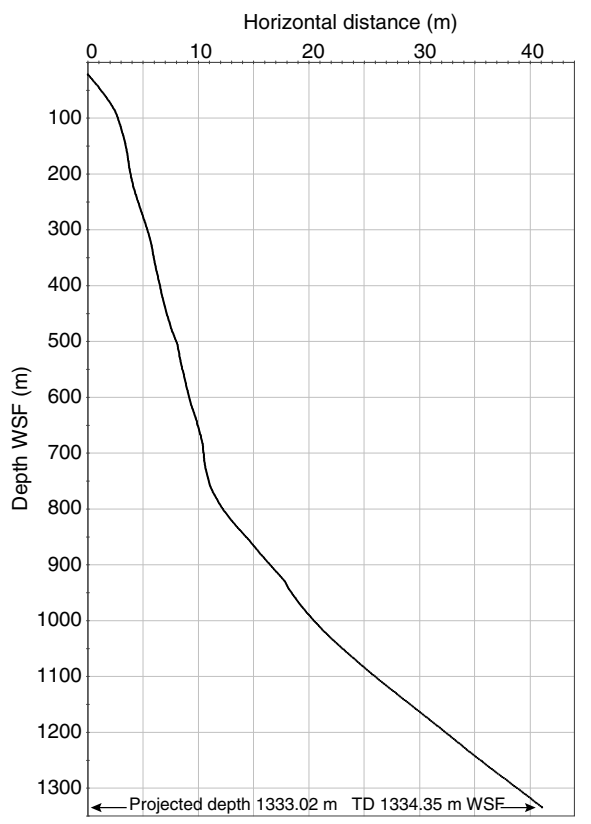

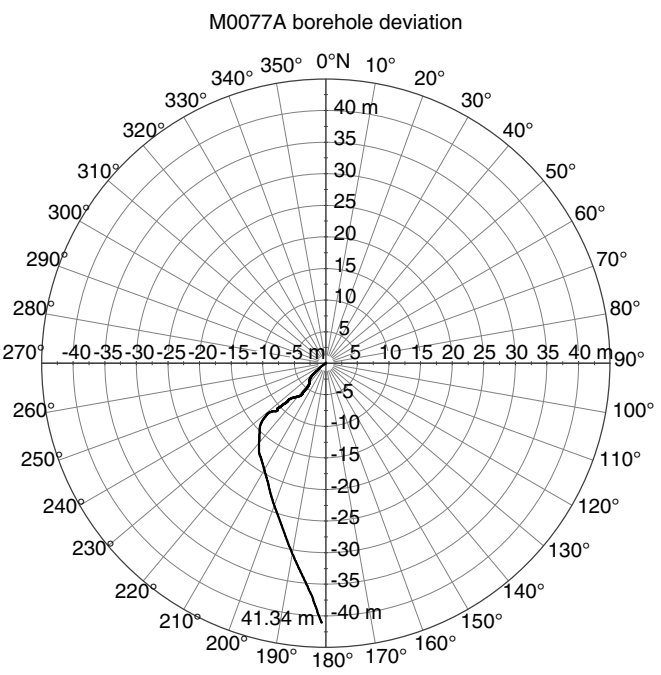




\section{Preliminary scientific assessment}

Expedition 364 is expected to achieve the majority of its predrilling scientific goals.

We recovered core through the peak ring and found it to comprise shocked, fractured granitoid basement intruded by pre-impact dikes, suevite, and impact melt rock overlain by impact melt rock and suevite. The fact that the peak ring is formed from uplifted, shocked, fractured granitic rocks that overlie Mesozoic sedimentary rocks (as observed in seismic reflection data) demonstrates that the dynamic collapse model for peak-ring formation is substantially correct (Morgan et al., 2016). Deformation of the peak-ring rocks includes brittle fractures, cataclasites, and pervasive shearing with striations that often crosscut each other. These observations will be used to address the kinematics of peak-ring formation and the weakening mechanism that governs impact crater formation in large impacts. The physical properties of these rocks demonstrate that the impact process reduces the density and velocity of target rocks and greatly enhances porosity.

The Post-Impact Sedimentary Rocks interval comprises a mix of lithologies, including marlstones, claystones, limestones, siltstones, and black shales, constrained biostratigraphically to be deposited between 49 and $66 \mathrm{Ma}$. The lower Paleocene is relatively condensed but complete, with fossils indicative of planktic foraminifer Biozones P $\alpha$ to P4. These initial results suggest that we will be able to address questions about the recovery of life in the ocean basin and directly compare the recovery with the evolving ocean chemistry. Nannofossil biostratigraphy indicates that the PETM is present at Site M0077 and is bracketed by unconformities, and the Eocene section above is relatively thick.

In terms of the deep biosphere within the impact crater, we ask what effect a large impact has on the deep subsurface biosphere and whether impacts can generate habitats for chemosynthetic life. How long did an impact-induced hydrothermal system exist, and what is the relationship between hydrothermal processes and habitability of the impact crater? Cell counts and DNA in the peak-ring rocks indicate the presence of modern microbial life, suggesting suevites provide an ecological niche. This possibility is now being confirmed with additional tests. Hydrothermal minerals are commonly observed in the peak-ring rocks, demonstrating that hydrothermal processes were active after this impact.

In summary, the nearly $100 \%$ core recovery, high quality of the recovered core, completeness of the early Paleocene, and successful wireline logging campaign at Site M0077 represent a great success. We are confident that the data acquired during Expedition 364 will accomplish the goals of the expedition and go a significant way toward answering the many questions posed about the impact crater, the end-Cretaceous mass extinction, and the effects of impacts on the deep biosphere.

\section{References}

Abramov, O., and Kring, D.A., 2007. Numerical modeling of impact-induced hydrothermal activity at the Chicxulub crater. Meteoritics E Planetary Science, 42(1):93-112. https://doi.org/10.1111/j.1945-5100.2007.tb00220.x

Ames, D.E., Kjarsgaard, I.M., Pope, K.O., Dressler, B., and Pilkington, M., 2004. Secondary alteration of the impactite and mineralization in the basal Tertiary sequence, Yaxcopoil-1, Chicxulub impact crater, Mexico. Meteoritics \& Planetary Science, 39(7):1145-1168. https://doi.org/10.1111/j.1945-5100.2004.tb01134.x
Artemieva, N., and Morgan, J., 2009. Modeling the formation of the K-Pg boundary layer. Icarus, 201(2):768-780. https://doi.org/10.1016/j.icarus.2009.01.021

Arz, J.A., Alegret, L., and Arenillas, I., 2004. Foraminiferal biostratigraphy and paleoenvironmental reconstruction at the Yaxcopoil-1 drill hole, Chicxulub crater, Yucatán Peninsula. Meteoritics \& Planetary Science, 39(7):1099-1111. https://doi.org/10.1111/j.1945-5100.2004.tb01131.x

Baker, D.M.H., Head, J.W., Collins, G.S., and Potter, R.W.K., 2016. The formation of peak-ring basins: working hypotheses and path forward in using observations to constrain models of impact-basin formation. Icarus, 273:146-163. https://doi.org/10.1016/j.icarus.2015.11.033

Barton, P.J., Grieve, R.A.F., Morgan, J.V., Surendra, A.T., Vermeesch, P.M., Christeson, G.L., Gulick, S.P.S., and Warner, M.R., 2010. Seismic images of Chicxulub impact melt sheet and comparison with the Sudbury structure. In Gibson, R.L., and Reimold, W.U. (Eds.), Large Meteorite Impacts and Planetary Evolution IV. Special Paper-Geological Society of America, 465:103-113. https://doi.org/10.1130/2010.2465(07)

Belcher, C.M., Hadden R.M., Rein, G., Morgan, J.V., Artemieva, N., and Goldin, T., 2015. An experimental assessment of the ignition of forest fuels by the thermal pulse generated by the Cretaceous-Palaeogene impact at Chicxulub. Journal of the Geological Society, 172(2):175-185. https://doi.org/10.1144/jgs2014-082

Bell, C., Morgan, J.V., Hampson, G.J., and Trudgill, B., 2004. Stratigraphic and sedimentological observations from seismic data across the Chicxulub impact basin. Meteoritics \& Planetary Science, 39(7):1089-1098. https://doi.org/10.1111/j.1945-5100.2004.tb01130.x

Bralower, T.J., Premoli Silva, I., and Malone, M.J., 2006. Leg 198 synthesis: a remarkable 120-m.y. record of climate and oceanography from Shatsky Rise, northwest Pacific Ocean. In Bralower, T.J., Premoli Silva, I., and Malone, M.J. (Eds.), Proceedings of the Ocean Drilling Program, Scientific Results, 198: College Station, TX (Ocean Drilling Program), 1-47. https://doi.org/10.2973/odp.proc.sr.198.101.2006

Bryce, C.C., Horneck, G., Rabbow, E., Edwards, H.G.M., and Cockell, C.S., 2015. Impact shocked rocks as protective habitats on an anoxic early Earth. International Journal of Astrobiology, 14(01):115-122. https://doi.org/10.1017/S1473550414000123

Christeson, G.L., Collins, G.S., Morgan, J.V., Gulick, S.P.S., Barton, P.J., and Wharton, M.R., 2009. Mantle deformation beneath the Chicxulub impact crater. Earth and Planetary Science Letters, 284(1-2):249-257. https://doi.org/10.1016/j.epsl.2009.04.033

Claeys, P., Heuschkel, S., Lounejeva-Baturina, E., Sanchez-Rubio, G., and Stöffler, D., 2003. The suevite of drill hole Yucàtan 6 in the Chicxulub impact crater. Meteoritics \& Planetary Science, 38(9):1299-1317. https://doi.org/10.1111/j.1945-5100.2003.tb00315.x

Cockell, C.S., Gronstal, A.L., Voytek, M.A., Kirshtein, J.D., Finster, K., Sanford, W.E., Glamoclija, M., Gohn, G.S., Powars, D.S., and Wright Horton, J., Jr., 2009. Microbial abundance in the deep subsurface of the Chesapeake Bay impact crater: relationship to lithology and impact processes. In Gohn, G.S., Koeberl, C., Miller, K.G., and Reimold, W.U. (Eds.), The ICDP-USGS Deep Drilling Project in the Chesapeake Bay Impact Structure: Results from the Eyreville Core Holes. Special Paper-Geological Society of America, 458:941-950. https://doi.org/10.1130/2009.2458(40)

Cockell, C.S., Lee, P., Broady, P., Lim, D.S.S., Osinski, G.R., Parnell, J., Koeberl, C., Pesonen, L., and Salminen, J., 2005. Effects of asteroid and comet impacts on habitats for lithophytic organisms-a synthesis. Meteoritics $\mathcal{E}$ Planetary Science, 40(12):1901-1914. https://doi.org/10.1111/j.1945-5100.2005.tb00153.x

Cockell, C.S., Lee, P., Osinski, G., Horneck, G., and Broady, P., 2002. Impactinduced microbial endolithic habitats. Meteoritics \& Planetary Science, 37(10):1287-1298.

https://doi.org/10.1111/j.1945-5100.2002.tb01029.x

Collins, G.S., 2014. Numerical simulations of impact crater formation with dilatancy. Journal of Geophysical Research: Planets, 119(12):2600-2619. https://doi.org/10.1002/2014JE004708 
Collins, G.S., Melosh, H.J., Morgan, J.V., and Warner, M.R., 2002. Hydrocode simulations of Chicxulub crater collapse and peak-ring formation. Icarus, 157(1):24-33. https://doi.org/10.1006/icar.2002.6822

Collins, G.S., Morgan, J., Barton, P., Christeson, G.L., Gulick, S., Urrutia, J., Warner, M., and Wünnemann, K., 2008. Dynamic modeling suggests terrace zone asymmetry in the Chicxulub crater is caused by target heterogeneity. Earth and Planetary Science Letters, 270(3-4):221-230. https://doi.org/10.1016/j.epsl.2008.03.032

Coolen, M.J.L., Orsi, W.D., Balkema, C., Quince, C., Harris, K., Sylva, S.P., Filipova-Marinova, M., and Giosan, L., 2013. Evolution of the plankton paleome in the Black Sea from the Deglacial to Anthropocene. Proceedings of the National Academy of Sciences of the United States of America, 110(21):8609-8614. https://doi.org/10.1073/pnas.1219283110

Coolen, M.J.L., and Overmann, J., 2007. 217 000-year-old DNA sequences of green sulfur bacteria in Mediterranean sapropels and their implications for the reconstruction of the paleoenvironment. Environmental Microbiology, 9(1):238-249. https://doi.org/10.1111/j.1462-2920.2006.01134.x

Gelinas, A., Kring, D.A., Zurcher, L., Urrutia-Fucugauchi, J., Morton, O., and Walker, R.J., 2004. Osmium isotope constraints on the proportion of bolide component in Chicxulub impact melt rocks. Meteoritics \& Planetary Science, 39(6):1003-1008. https://doi.org/10.1111/j.1945-5100.2004.tb00941.x

Goderis, S., Paquay, F., and Claeys, P., 2012. Projectile identification in terrestrial impact structures and ejecta material. In Osinski, G.R., and Pierazzo, E. (Eds.), Impact Cratering: Process and Products: Oxford, United Kingdom (Blackwell Publishing, Ltd.), 223-235. https://doi.org/10.1002/9781118447307.ch15

Goto, K., Tada, R., Tajika, E., Bralower, T.J., Hasegawa, T., and Matsui, T., 2004. Evidence for ocean water invasion into the Chicxulub crater at the Cretaceous/Tertiary boundary. Meteoritics \& Planetary Science, 39(7):1233-1247. https://doi.org/10.1111/j.1945-5100.2004.tb01139.x

Grieve, R.A.F., Langenhorst, F., and Stöffler, D., 1996. Shock metamorphism of quartz in nature and experiment: II. Significance in geoscience. Meteoritics \& Planetary Science, 31(1):6-35. https://doi.org/10.1111/j.1945-5100.1996.tb02049.x

Grieve, R.A.F., Reimold, W.U., Morgan, J., Riller, U., and Pilkington, M., 2008. Observations and interpretations at Vredefort, Sudbury, and Chicxulub: towards an empirical model of terrestrial impact basin formation. Meteoritics \& Planetary Science, 43(5):855-882.

https://doi.org/10.1111/j.1945-5100.2008.tb01086.x

Gulick, S.P.S., Barton, P.J., Christeson, G.L., Morgan, J.V., McDonald, M., Mendoza-Cervantes, K., Pearson, Z.F., Surendra, A., Urrutia-Fucugauchi, J., Vermeesch, P.M., and Warner, M.R., 2008. Importance of pre-impact crustal structure for the asymmetry of the Chicxulub impact crater. Nature Geoscience, 1(2):131-135. https://doi.org/10.1038/ngeo103

Gulick, S.P.S., Christeson, G.L., Barton, P.J., Grieve, R.A.F., Morgan, J.V., and Urrutia-Fucugauchi, J., 2013. Geophysical characterization of the Chicxulub impact crater. Reviews of Geophysics, 51(1):31-52. https://doi.org/10.1002/rog.20007

Hecht, L., Wittmann, A., Schmitt, R.-T., and Stöffler, D., 2004. Composition of impact melt particles and the effects of post-impact alteration in suevitic rocks at the Yaxcopoil-1 drill core, Chicxulub crater, Mexico. Meteoritics E Planetary Science, 39(7):1169-1186. https://doi.org/10.1111/j.1945-5100.2004.tb01135.x

Hildebrand, A.R., Penfield, G.T., Kring, D.A., Pilkington, M., Camargo, A.Z., Jacobsen, S.B., and Boynton, W.V., 1991. Chicxulub crater: a possible Cretaceous/Tertiary boundary impact crater on the Yucatán Peninsula, Mexico. Geology, 19(9):867-871. https://doi.org/10.1130/00917613(1991)019<0867:CCAPCT >2.3.CO;2

Huber, M.S., Ferrière, L., Losiak, A., and Koeberl, C., 2011. ANIE: a mathematical algorithm for automated indexing of planar deformation features in quartz grains. Meteoritics \& Planetary Science, 46(9):1418-1424. https://doi.org/10.1111/j.1945-5100.2011.01234.x

Ivanov, B.A., 1994. Geomechanical models of impact cratering: PuchezhKatunki structure. In Dressier, B.O., Grieve, R.A.F., and Sharpton, V.L.
(Eds.), Large Meteorite Impacts and Planetary Evolution. Special PaperGeological Society of America, 293:81-92.

https://doi.org/10.1130/SPE293-p81

Ivanov, B.A., 2005. Numerical modeling of the largest terrestrial meteorite craters. Solar System Research, 39(5):381-409. https://doi.org/10.1007/s11208-005-0051-0

Jiang, S., Bralower, T.J., Patzkowsky, M.E., Kump, L.R., and Schueth, J.D., 2010. Geographic controls on nannoplankton extinction across the Cretaceous/Palaeogene boundary. Nature Geoscience, 3(4):280-285. https://doi.org/10.1038/ngeo775

John, C.M., Banerjee, N.R., Longstaffe, F.J., Sica, C., Law, K.R., and Zachos, J.C., 2012. Clay assemblage and oxygen isotopic constraints on the weathering response to the Paleocene-Eocene Thermal Maximum, east coast of North America. Geology, 40(7):591-594. https://doi.org/10.1130/G32785.1

Kenkmann, T., 2003. Dike formation, cataclastic flow, and rock fluidization during impact cratering: an example from the Upheaval Dome structure, Utah. Earth and Planetary Science Letters, 214(1-2):43-58. https://doi.org/10.1016/S0012-821X(03)00359-5

Kenkmann, T., Jahn, A., Scherler, D., and Ivanov, B.A., 2005. Structure and formation of a central uplift: a case study at the Upheaval Dome impact crater, Utah. In Kenkmann, T., Hörz, F., and Deutsch, A. (Eds.), Large Meteorite Impacts III. Special Paper-Geological Society of America, 384:85-115. https://doi.org/10.1130/0-8137-2384-1.85

Kenkmann, T., Wittmann, A., and Scherler, D., 2004. Structure and impact indicators of the Cretaceous sequence of the ICDP drill core Yaxcopoil-1, Chicxulub impact crater, Mexico. Meteoritics \& Planetary Science, 39(7):1069-1088. https://doi.org/10.1111/j.1945-5100.2004.tb01129.x

Kettrup, B., Deutsch, A., Ostermann, M., and Agrinier, P., 2000. Chicxulub impactites: geochemical clues to the precursor rocks. Meteoritics $\mathcal{E}$ Planetary Science, 35(6):1229-1238. https://doi.org/10.1111/j.1945-5100.2000.tb01511.x

Koeberl, C., Claeys, P., Hecht, L., and McDonald, I., 2012. Geochemistry of impactites. Elements, 8(1):37-42. https://doi.org/10.2113/gselements.8.1.37

Kring, D.A., 2005. Hypervelocity collisions into continental crust composed of sediments and an underlying crystalline basement: comparing the Ries $(\sim 24 \mathrm{~km})$ and Chicxulub ( 180 km) impact craters. Chemie der ErdeGeochemistry, 65(1):1-46. https://doi.org/10.1016/j.chemer.2004.10.003

Kring, D.A., and Cohen, B.A., 2002. Cataclysmic bombardment throughout the inner solar system 3.9-4.0 Ga. Journal of Geophysical Research: Planets, 107(E2):1-6. https://doi.org/10.1029/2001JE001529

Kring, D.A., Hörz, F., Zurcher, L., and Urrutia Fucugauchi, J., 2004. Impact lithologies and their emplacement in the Chicxulub impact crater: initial results from the Chicxulub Scientific Drilling Project, Yaxcopoil, Mexico. Meteoritics \& Planetary Science, 39(6):879-897. https://doi.org/10.1111/j.1945-5100.2004.tb00936.x

Lieger, D., Riller, U., and Gibson, R.L., 2009. Generation of fragment-rich pseudotachylite bodies during central uplift formation in the Vredefort impact structure, South Africa. Earth and Planetary Science Letters, 279(1-2):53-64. https://doi.org/10.1016/j.epsl.2008.12.031

Lüders, V., and Rickers, K., 2004. Fluid inclusion evidence for impact-related hydrothermal fluid and hydrocarbon migration in Cretaceous sediments of the ICDP-Chicxulub drill core Yaxcopoil-1. Meteoritics E Planetary Science, 39(7):1187-1197. https://doi.org/10.1111/j.1945-5100.2004.tb01136.x

Melosh, H.J., 1979. Acoustic fluidization: a new geologic process? Journal of Geophysical Research: Solid Earth, 84(B13):7513-7520. https://doi.org/10.1029/JB084iB13p07513

Melosh, H.J., and Ivanov, B.A., 1999. Impact crater collapse. Annual Review of Earth and Planetary Sciences, 27(1):385-415. https://doi.org/10.1146/annurev.earth.27.1.385

Mohr-Westheide, T., Reimold, W.U., Riller, U., and Gibson, R.L., 2009. Pseudotachylitic breccia and microfracture networks in Archean gneiss of the central uplift of the Vredefort Impact Structure, South Africa. South 
African Journal of Geology, 112(1):1-22.

https://doi.org/10.2113/gssajg.112.1.1

Morgan, J., Artemieva, N., and Goldin, T., 2013. Revisiting wildfires at the KPg boundary. Journal of Geophysical Research: Biogeosciences, 118(4):1508-1520. https://doi.org/10.1002/2013JG002428

Morgan, J.V.,Gulick, S.P. S., Bralower, T., Chenot, E., Christeson, G., Claeys, P. Cockell, C., Collins, G.S., Coolen, M.J.L., Ferrière, L., Gebhardt, C., Goto, K., Jones, H., Kring, D.A., Le Ber, E., Lofi, J., Long, X., Lowery, C., Mellet, C., Ocampo-Torres, R., Osinski, G.R., Perez-Cruz, L., Pickersgill, A., Poelchau, M., Rae, A., Rasmussen, C., Rebolledo-Vieyra, M., Riller, U., Sato, H., Schmitt, D.R., Smit, J., Tikoo, S., Tomioka, N., Urrutia-Fucugauchi, J., Whalen, M., Wittmann, A., Yamaguchi, K.E., and Zylberman, W., 2016. The formation of peak rings in large impact craters. Science, 354(6314):878-882. https://doi.org/10.1126/science.aah6561

Morgan, J., and Warner, M., 1999. Chicxulub: the third dimension of a multiring impact basin. Geology, 27(5):407-410.

https://doi.org/10.1130/00917613(1999) $027<0407:$ CTTDOA $>2.3 . C O ; 2$

Morgan, J.V., Warner, M., the Chicxulub Working Group, Brittan, J., Buffler, R., Carmargo, A., Christeson, G., Denton, P., Hildebrand, A., Hobbs, R., Macintyre, H., Mackenzie, G., Maguire, P., Marin, L., Nakamura, Y., Pilkington, M., Sharpton, V., Snyder, D., Suarez, G., and Trejo, A., 1997. Size and morphology of the Chicxulub impact crater. Nature, 390(6659):472476. https://doi.org/10.1038/37291

Morgan, J.V., Warner, M.R., Collins, G.S., Grieve, R.A.F., Christeson, G.L., Gulick, S.P.S., and Barton, P.J., 2011. Full waveform tomographic images of the peak ring at the Chicxulub impact crater. Journal of Geophysical Research: Solid Earth, 116(B6):B06303. https://doi.org/10.1029/2010JB008015

Morgan, J.V., Warner, M.R., Collins, G.S., Melosh, H.J., and Christeson, G.L., 2000. Peak-ring formation in large impact craters: geophysical constraints from Chicxulub. Earth and Planetary Science Letters, 183(3-4):347-354. https://doi.org/10.1016/S0012-821X(00)00307-1

O'Keefe, J.D., and Ahrens, T.J., 1993. Planetary cratering mechanics. Journal of Geophysical Research: Planets, 98(E9):17011-17028. https://doi.org/10.1029/93JE01330

Osinski, G.R., Lee, P., Parnell, J., Spray, J.G., and Baron, M., 2005. A case study of impact-induced hydrothermal activity: the Haughton impact structure, Devon Island, Canadian High Arctic. Meteoritics \& Planetary Science, 40(12):1859-1877. https://doi.org/10.1111/j.1945-5100.2005.tb00150.x

Osinski, G.R., Tornabene, L.L., Banerjee, N.R., Cockell, C.S., Flemming, R., Izawa, M.R.M., McCutcheon, J., Parnell, J., Preston, L.J., Pickersgill, A.E., Pontefract, A., Sapers, H.M., and Southam, G., 2013. Impact-generated hydrothermal systems on Earth and Mars. Icarus, 224(2):347-363. https://doi.org/10.1016/j.icarus.2012.08.030

Pickersgill, A.E., Osinksi, G.R., and Flemming, R.L., 2015. Shock effects in plagioclase feldspar from the Mistastin Lake impact structure, Canada. Meteoritics E Planetary Science, 50(9):1546-1561. https://doi.org/10.1111/maps.12495

Pierazzo, E., Hahmann, A.N., and Sloan, L.C., 2003. Chicxulub and climate: radioactive perturbations of impact-produced S-bearing gases. Astrobiology, 3(1):99-118. https://doi.org/10.1089/153110703321632453

Pope, K.O., Baines, K.H., Ocampo, A.C., and Ivanov, B.A., 1997. Energy, volatile production, and climatic effects of the Chicxulub Cretaceous/Tertiary impact. Journal of Geophysical Research: Planets, 102(E9):21645-21664. https://doi.org/10.1029/97JE01743

Quesnel, Y., Gattacceca, J., Osinski, G.R., and Rochette, P., 2013. Origin of the central magnetic anomaly at the Haughton impact structure, Canada. Earth and Planetary Science Letters, 367:116-122. https://doi.org/10.1016/j.epsl.2013.02.032

Rae, A.S.P., Morgan, J.V., Collins, G.S., Osinski, G.R., and Grieve, R.A.F., 2015. Observational constraints on structural uplift formation: the West Clearwater impact structure [presented at 46th Lunar and Planetary Science Conference, The Woodlands, Texas, 16-20 March 2015]. (Abstract 1451) http://www.hou.usra.edu/meetings/lpsc2015/pdf/1451.pdf
Rebolledo-Vieyra, M., and Urrutia-Fucugauchi, J., 2004. Magnetostratigraphy of the impact breccias and post-impact carbonates from borehole Yaxcopoil-1, Chicxulub impact crater, Yucatán, Mexico. Meteoritics \& Planetary Science, 39(6):821-830. https://doi.org/10.1111/j.1945-5100.2004.tb00932.x

Rebolledo-Vieyra, M., and Urrutia-Fucugauchi, J., 2006. Magnetostratigraphy of the Cretaceous/Tertiary boundary and early Paleocene sedimentary sequence from the Chicxulub impact crater. Earth, Planets and Space, 58(10):1309-1314. https://doi.org/10.1186/BF03352626

Reimold, W.U., and Gibson, R.L., 2005. "Pseudotachylites" in large impact structures. In Koeberl, C., and Henkel, H. (Eds.), Impact Studies (Volume 6): Impact Tectonics. Koeberl, C. (Series Ed.): New York (Springer-Verlag), 1-53. https://doi.org/10.1007/3-540-27548-7_1

Renne, P.R., Deino, A.L., Hilgen, F.J., Kuiper, K.F., Mark, D.F., Mitchell, W.S., III, Morgan, L.E., Mundil, R., and Smit, J., 2013. Time scales of critical events around the Cretaceous-Paleogene boundary. Science, 339(6120):684-687. https://doi.org/10.1126/science.1230492

Riller, U., and Lieger, D., 2008. Geological evidence for acoustic fluidization in large impact structures [presented at Large Meteorites and Planetary Evolution IV, Vredefort Dome, South Africa, 17-21 August 2008]. (Abstract 3025) http://www.lpi.usra.edu/meetings/lmi2008/pdf/3025.pdf

Riller, U., Lieger, D., Gibson, R.L. Grieve, R.A.F., and Stöffler, D., 2010. Origin of large-volume pseudotachylite in terrestrial impact structures. Geology, 38(7):619-622. https://doi.org/10.1130/G30806.1

Rowe, A.J., Wilkinson, J.J, Coles, B.J., and Morgan, J.V., 2004. Chicxulub: testing for post-impact hydrothermal inputs into the Tertiary ocean. Meteoritics E Planetary Science, 39(7):1223-1231. https://doi.org/10.1111/j.1945-5100.2004.tb01138.x

Sanford, J.C., Snedden, J.W., and Gulick, S.P.S., 2016. The Cretaceous-Paleogene boundary deposit in the Gulf of Mexico: large-scale oceanic basin response to the Chicxulub impact. Journal of Geophysical Research: Solid Earth, 121(3):1240-1261. https://doi.org/10.1002/2015JB012615

Sato, H., Onoue, T., Nozaki, T., and Suzuki, K., 2013. Osmium isotope evidence for a large late Triassic impact event. Nature Communications, 4:2455. https://doi.org/10.1038/ncomms3455

Sato, H., Shirai, N., Ebihara, M., Onoue, T., and Kiyokawa, S., 2016. Sedimentary PGE signatures in the late Triassic ejecta deposits from Japan: implications for the identification of impactor. Palaeogeography, Palaeoclimatology, Palaeoecology, 442:36-47. https://doi.org/10.1016/j.palaeo.2015.11.015

Schulte, P., Alegret, L., Arenillas, I., Arz, J.A., Barton, P.J., Bown, P.R., Bralower, T.J., Christeson, G.L., Claeys, P., Cockell, C.S., Collins, G.S., Deutsch, A., Goldin, T.J., Goto, K., Grajales-Nishimura, J.M., Grieve, R.A.F., Gulick, S.P.S., Johnson, K.R., Kiessling, W., Koeberl, C., Kring, D.A., MacLeod, K.G., Matsui, T., Melosh, J., Montanari, A., Morgan, J.V., Neal, C.R., Nichols, D.J., Norris, R.D., Pierazzo, E., Ravizza, G., Rebolledo-Vieyra, M., Reimold, W.U., Robin, E., Salge, T., Speijer, R.P., Sweet, A.R., Urrutia-Fucugauchi, J., Vajda, V., Whalen, M.T., and Willumsen, P.S., 2010. The Chicxulub asteroid impact and mass extinction at the Cretaceous-Paleogene boundary. Science, 327(5970):1214-1218. https://doi.org/10.1126/science.1177265

Schulte, P., Scheibner, C., and Speijer, R.P., 2011. Fluvial discharge and sealevel changes controlling black shale deposition during the PaleoceneEocene Thermal Maximum in the Dababiya Quarry section, Egypt. Chemical Geology, 285:167-183. https://doi.org/10.1016/j.chemgeo.2011.04.004

Schulte, P., Speijer, R., Mai, H., and Kontny, A., 2006. The Cretaceous-Paleogene (K-P) boundary at Brazos, Texas: sequence stratigraphy, depositional events and the Chicxulub impact. Sedimentary Geology, 184:77109. https://doi.org/10.1016/j.sedgeo.2005.09.021

Schwenzer, S.P., and Kring, D.A., 2009. Impact-generated hydrothermal systems capable of forming phyllosilicates on Noachian Mars. Geology, 37(12):1091-1094. https://doi.org/10.1130/G30340A.1

Senft, L.E., and Stewart, S.T., 2009. Dynamic fault weakening and the formation of large impact craters. Earth and Planetary Science Letters, 287(34):471-482. https://doi.org/10.1016/j.epsl.2009.08.033 
Sharpton, V.L., Marin, L.E., Carney, J.L., Lee, S., Ryder, G., Schuraytz, B.C., Sikora, P., and Spudis, P.D., 1996. A model of the Chicxulub impact basin based on evaluation of geophysical data, well logs, and drill core samples. In Ryder, G., Fastovsky, D.E, and Gartner, S. (Eds.), The Cretaceous-Tertiary Event and Other Catastrophes in Earth History. Special PaperGeological Society of America, 307:55-74.

https://doi.org/10.1130/0-8137-2307-8.55

Smit, J., Van Der Gaast, S., and Lustenhouwer, W., 2004. Is the transition impact to post-impact rock complete? Some remarks based on XRF scanning, electron microprobe, and thin section analyses of the Yaxcopoil-1 core in the Chicxulub crater. Meteoritics E Planetary Science, 39(7):11131126. https://doi.org/10.1111/j.1945-5100.2004.tb01132.x

Spray, J.G., 1992. A physical basis for the frictional melting of some rockforming minerals. Tectonophysics, 204(3-4):205-221. https://doi.org/10.1016/0040-1951(92)90308-S

Stöffler, D., Artemieva, N.A., Ivanov, B.A., Hecht, L., Kenkmann, T., Schmitt, R.T., Tagle, R.A., and Wittmann, A., 2004. Origin and emplacement of the impact formations at Chicxulub, Mexico, as revealed by the ICDP deep drilling at Yaxcopoil-1 and by numerical modeling. Meteoritics \& Planetary Science, 39(7):1035-1067. https://doi.org/10.1111/j.1945-5100.2004.tb01128.x

Tagle, R., and Hecht, L., 2006. Geochemical identification of projectiles in impact rocks. Meteoritics \& Planetary Science, 41(11):1721-1735. https://doi.org/10.1111/j.1945-5100.2006.tb00448.x

Tikoo, S.M., Gattacceca, J., Swanson-Hysell, N.L., Weiss, B.P., Suavet, C., and Cournède, C., 2015. Preservation and detectability of shock-induced magnetization. Journal of Geophysical Research: Planets, 120(9):14611475. https://doi.org/10.1002/2015JE004840

Tomioka, N., Tomeoka, K., Nakamura-Messenger, K., and Sekine, T., 2007. Heating effects of the matrix of experimentally shocked Murchison CM chondrite: comparison with micrometeorites. Meteoritics E Planetary Science, 42(1):19-30. https://doi.org/10.1111/j.1945-5100.2007.tb00214.x

Trinquier, A., Birck, J.-L., and Allègre, C.J., 2006. The nature of the KT impactor. A ${ }^{54} \mathrm{Cr}$ reappraisal. Earth and Planetary Science Letters, 241(34):780-788. https://doi.org/10.1016/j.epsl.2005.11.006

Urrutia-Fucugauchi, J., Camargo-Zanoguera, A., Pérez-Cruz, L., and PérezCruz, G., 2011. The Chicxulub multi-ring impact crater, Yucatán carbonate platform, Gulf of Mexico. Geofísica Internacional, 50(1):99-127. http://www.scielo.org.mx/pdf/geoint/v50n1/v50n1a9.pdf

Urrutia-Fucugauchi, J., Chavez-Aguirre, J.M., Pérez-Cruz, L., and De La Rosa, J.L., 2008. Impact ejecta and carbonate sequence in the eastern sector of the Chicxulub crater. Comptes Rendus Geoscience, 341(12):801-810. https://doi.org/10.1016/j.crte.2008.09.001

Urrutia-Fucugauchi, J., Marin, L., and Sharpton, V.L., 1994. Reverse polarity magnetized melt rocks from the Cretaceous/Tertiary Chicxulub structure, Yucatan peninsula, Mexico. Tectonophysics, 237(1-2):105-112. https://doi.org/10.1016/0040-1951(94)90161-9

Urrutia-Fucugauchi, J., Marin, L., and Trejo-Garcia, A., 1996. UNAM scientific drilling program of Chicxulub impact structure-evidence for a 300 kilometer crater diameter. Geophysical Research Letters, 23(13):15651568. https://doi.org/10.1029/96GL01566

Urrutia-Fucugauchi, J., Morgan, J., Stöffler, D., and Claeys, P., 2004a. The Chicxulub Scientific Drilling Project (CSDP). Meteoritics \& Planetary Science, 39(6):787-790. https://doi.org/10.1111/j.1945-5100.2004.tb00928.x

Urrutia-Fucugauchi, J., Soler-Arechalde, A.M., Rebolledo-Vieyra, M., and Vera-Sanchez, P., 2004b. Paleomagnetic and rock magnetic study of the Yaxcopoil-1 impact breccia sequence, Chicxulub impact crater (Mexico). Meteoritics \& Planetary Science, 39(6):843-856. https://doi.org/10.1111/j.1945-5100.2004.tb00934.x

Velasco-Villareal, M., Urrutia-Fucugauchi, J., Rebolledo-Vieyra, M., and Perez-Cruz, L., 2011. Paleomagnetism of impact breccias from the Chicx- ulub crater-implications for ejecta emplacement and hydrothermal processes. Physics of the Earth and Planetary Interiors, 186(3-4):154-171. https://doi.org/10.1016/j.pepi.2011.04.003

Vellekoop, J., Sluijs, A., Smit, J., Schouten, S., Weijers, J.W.H., Sinninghe Damsté, J.S., and Brinkhuis, H., 2014. Rapid short-term cooling following the Chicxulub impact at the Cretaceous-Paleogene boundary. Proceedings of the National Academy of Sciences of the United States of America, 111(21):7537-7541. https://doi.org/10.1073/pnas.1319253111

Vermeesch, P.M., and Morgan, J.V., 2008. Structural uplift beneath the Chicxulub impact structure. Journal of Geophysical Research: Solid Earth, 113(B7):B07103. https://doi.org/10.1029/2007JB005393

Ward, W.C., Keller, G., Stinnesbeck, W., and Adatte, T., 1995. Yucatán subsurface stratigraphy: implications and constraints for the Chicxulub impact. Geology, 23(10):873-876. https://doi.org/10.1130/00917613(1995)023<0873:YNSSIA > 2.3.CO;2

Whalen, M.T., Gulick, S.P.S., Pearson, Z.F., Norris, R.D., Perez Cruz, L., and Urrutia Fucugauchi, J., 2013. Annealing the Chicxulub impact: Paleogene Yucatàn carbonate slope development in the Chicxulub impact basin, Mexico. In Verwer, K., Playton, T.E., and Harris, P.M. (Eds.), Deposits, Architecture, and Controls of Carbonate Margin, Slope and Basinal Settings. Special Publication - SEPM (Society for Sedimentary Geology), 105:282-304. https://doi.org/10.2110/sepmsp.105.04

Whalen, M.T., Pearson, Z.F., Gulick, S.P.S., and Norris, R.D., 2008. Sequence stratigraphy of the Chicxulub crater infill and Yucatán carbonate platform development: implications for the evolution of large terrestrial impact craters. Geological Society of America Abstracts with Programs, 40(6):407. https://gsa.confex.com/gsa/2008AM/finalprogram/abstract_151599.htm

Wittmann, A., Kenkmann, T., Hecht, L., and Stöffler, D., 2007. Reconstruction of the Chicxulub ejecta plume from its deposits in drill core Yaxcopoil-1. Geological Society of America Bulletin, 119(9-10):1151-1167. https://doi.org/10.1130/B26116.1

Wittmann, A., Kenkmann, T., Schmitt, R.T., Hecht, L., and Stöffler, D., 2004. Impact-related dike breccia lithologies in the ICDP drill core Yaxcopoil-1, Chicxulub impact structure, Mexico. Meteoritics \& Planetary Science, 39(6):931-954. https://doi.org/10.1111/j.1945-5100.2004.tb00938.x

Wittmann, A., Schmitt, R.T., Hecht, L., Kring, D.A., Reimold, W.U., and Povenmire, H., 2009. Petrology of impact melt rocks from the Chesapeake Bay crater, USA. Special Paper - Geological Association of America, 458:377-396. https://doi.org/10.1130/2009.2458(17)

Wünnemann, K., Morgan, J.V., and Jödicke, H., 2005. Is Ries crater typical for its size? An analysis based upon old and new geophysical data and numerical modeling. In Kenkmann, T., Hörz, F., and Deutsch, A. (Eds.), Large Meteorite Impacts III. Special Paper-Geological Society of America, 384:67-83. https://doi.org/10.1130/0-8137-2384-1.67

Yamaguchi, K.E., Johnson, C.M., Beard, B.L., and Ohmoto, H., 2005. Biogeochemical cycling of iron in the Archean-Paleoproterozoic Earth: constraints from iron isotope variations in sedimentary rocks from the Kaapvaal and Pilbara Cratons. Chemical Geology, 218(1-2):135-169. https://doi.org/10.1016/j.chemgeo.2005.01.020

Zachos, J.C., Lohmann, K.C., Walker, J.C.G., and Wise, S.W., Jr., 1993. Abrupt climate change and transient climates during the Paleogene: a marine perspective. Journal of Geology, 101(2):191-213. https://doi.org/10.1086/648216

Zachos, J., Pagani, M., Sloan, L., Thomas, E., and Billups, K., 2001. Trends, rhythms, and aberrations in global climate $65 \mathrm{Ma}$ to present. Science, 292(5517):686-693. https://doi.org/10.1126/science.1059412

Zürcher, L., and Kring, D.A., 2004. Hydrothermal alteration in the core of the Yaxcopoil-1 borehole, Chicxulub impact structure, Mexico. Meteoritics $\mathcal{E}$ Planetary Science, 39(7):1199-1221. https://doi.org/10.1111/j.1945-5100.2004.tb01137.x 